\title{
A CONCEPÇÃO KANTIANA DA EXPERIÊNCIA ESTÉTICA: NOVIDADES, TENSÕES E EQUILÍBRIOS
}

\author{
Leonel Ribeiro dos Santos ${ }^{1}$
}

RESUMO: Neste ensaio proponho-me identificar alguns aspectos peculiares da problematização kantiana da experiência estética, assinalando as suas tensões e os equilíbrios que a sustentam e mostrar que a sua fecundidade especulativa não se esgota no aproveitamento que a geração póskantiana (do Classicismo, Romantismo e Idealismo) fez de alguns dos seus elementos, mas continua a revelar-se na redescoberta que, nas últimas décadas, dela vem sendo feita e cujo alcance se tem provado na capacidade que oferece para revitalizar os debates actuais acerca dos problemas estéticos. Tento mostrar, nomeadamente, que a meditação kantiana representa um singular momento de equilíbrio instável entre dois regimes de pensamento estético: um, que gira em torno da categoria do gosto (Geschmack), entendido como um senso comum estético que invoca uma preocupação social e comunitária, o outro, que gira em torno da categoria do génio (Genie) e do pressuposto do carácter absoluto da individualidade e subjectividade criadora; um, que reabilita a sensibilidade humana (Sinnlichkeit) e as qualidades sensíveis dos objectos enquanto contempladas e apreciadas pelo sujeito, o outro, centrado na categoria do sentimento íntimo (Gefühl), entendido como algo inalienável e como o irredutivelmente subjectivo da vivência individual.

PALAVRAS-CHAVE: Experiência estética. Estética kantiana. Génio. Gosto. Sensibilidade. Sentimento.

\section{Sinopse}

Constitui um dos aspectos mais relevantes do interesse pela filosofia de Kant nas últimas quatro décadas, a par com a descoberta da filosofia

${ }^{1}$ CFUL - Faculdade de Letras da Universidade de Lisboa. E-mail: leonelrs@netcabo.pt 
prática (entendida, no seu sentido amplo, como Filosofia Moral, Filosofia Política e Filosofia do Direito), a descoberta da terceira Crítica, a Crítica do Juízo (Kritik der Urteilskraft, 1790), cuja primeira parte se intitula «Crítica do juízo estético». Na verdade, mesmo que a intenção de Kant, ao escrever essa Primeira Parte da sua Crítica do Juízo, não fosse propor uma «Estética», à maneira de Baumgarten, e ainda menos uma «Filosofia da Arte ou das Artes» - embora tenha dado para esta última interessantes indicações, em alguns dos parágrafos da obra -, a sua singular abordagem dos problemas estéticos, sob a forma de "Crítica do juízo estético» ou "Crítica do juízo de gosto», representa um marco decisivo na história do pensamento estético, o qual, se por um lado confirma e consagra o reconhecimento da natureza peculiar da experiência e sentimento estéticos e a respectiva irredutibilidade e autonomia frente à experiência científica e ética, por outro, assinala aquilo a que já se chamou a "viragem para a Estética», ou seja, o reconhecimento da importância fundamental da experiência estética e até do primado da Arte, no sistema das realizações superiores do espírito, o que veio a ser protagonizado na cultura germânica pelos movimentos classicista, romântico e idealista de finais do século XVIII e começos do século XIX, com reflexos e efeitos directos ou diferidos por todo o espaço da cultura europeia oitocentista.

A estratégia seguida por Kant, no tratamento das questões estéticas, não visa propor uma filosofia do belo ou uma teoria das belas artes, nem fornecer uma descrição das obras de arte e das suas qualidades estéticas. O que ele faz é verdadeiramente o que se poderia chamar uma abordagem fenomenológica, dada sob a forma de uma análise da experiência estética do juízo estético ou juízo de gosto - no intuito de captar, interpretar e compreender o que nela está envolvido. Esse tipo de abordagem é o que Kant designa por "crítica» e, por isso, a meditação kantiana sobre os problemas estéticos dá-se como uma "Crítica do juízo estético» ou "crítica do gosto». O que é que acontece ou está em causa quando dizemos (ou pensamos para nós próprios), a propósito, por exemplo, de uma flor que encontramos na natureza ou num jardim, que ela é bela? Contrapondo-se a uma teoria normativa do gosto, a crítica do juízo estético explicita-se antes como uma analítica do mesmo, tendo em vista surpreender a sua especificidade e características (o que o distingue seja da simples sensação de agrado sensível, seja de outros tipos de juízos: lógico-cognitivos, morais), a sua tipologia (sentimento do belo e sentimento do sublime), a faculdade do espírito a cuja competência pertence, o princípio que invoca, que o legitima ou o fundamenta; enfim, aquilo a que, na linguagem kantiana, se chama os seus pressupostos transcendentais. Mas a crítica kantiana atende igualmente à dialéctica ou às antinomias com que se debate o juízo estético: é ele um juízo meramente singular e privado, ou um juízo com valor universal? É um juízo meramente subjectivo, ou possui algum tipo de objectividade? 
O reconhecimento da importância do que hoje consideramos o campo dos problemas estéticos (noção de arte e de bela arte, constituição do sistema das artes, análise e fenomenologia dos sentimentos estéticos e da vivência estética, concepção do artista e do génio) desenvolveu-se na cultura europeia com particular intensidade a partir do século XV, a par com o próprio renascimento e florescimento artístico, e a reflexão dos filósofos sobre esses problemas atingiu a maturidade ao longo do século XVIII e primeiras décadas do século XIX, sendo que a própria meditação kantiana sobre esses tópicos constitui tanto um ponto de culminância como um ponto de viragem, representando um momento de instável equilíbrio entre dois regimes ou paradigmas de pensamento estético: um, girando em torno da categoria do gosto, noção ainda fortemente marcada por um sentido social e concebido mesmo como uma espécie de "sentido comum» ou de "sentido comunitário» (gemein Sinn, gemeinchaftliches Sinn); o outro, centrado na categoria do génio e no consequente pressuposto do carácter absoluto da individualidade e subjectividade criadora; um, assente na reabilitação da sensibilidade humana (Sinnlichkeit) e das qualidades sensíveis dos objectos do mundo contemplados ou apreciados pelo sujeito; o outro, centrado na ideia do sentimento (Gefühl), entendido como algo inalienável e irredutivelmente subjectivo da vivência individual.

\section{A especificidade do estético: da sensibilidade ao sentimento}

Coube ao filósofo alemão Alexandre Baumgarten, um original seguidor da escola leibniziano-wolffiana, o mérito de sistematizar a abordagem das questões estéticas numa nova disciplina filosófica a que chamou precisamente Aesthetica, cujo $1^{\circ}$ volume foi publicado em 1750 (o $2^{\circ}$ sê-lo-ia em 1758). Os assuntos estéticos até então ou eram tratados à mistura com reflexões de natureza moral e psicológica (a propósito dos sentimentos), ou com considerações metafísicas (a ideia de beleza convocava as - ou era convocada pelas - de perfeição, de harmonia, de ordem, de simetria, de regularidade), ou, pelo que respeitava aos aspectos expressivos, eram tópicos dos Tratados de Poética e de Retórica, que haviam conhecido grande proliferação no período do Barroco. Desenharam-se assim três linhas de reflexão relativamente autónomas, mas que por vezes se cruzaram, nas quais se alinhavam os diferentes autores segundo as suas afinidades ou preocupações dominantes: uma linha de reflexão prevalentemente metafísica sobre a ideia de beleza, no seguimento da tradição platónica e neoplatónica, que fora reavivada na segunda metade do século XV por Marsílio Ficino e que, no pensamento alemão moderno, fora protagonizada por Leibniz e seus discípulos e, na época de Kant, era representada pelo seu amigo Moses Mendelssohn; uma linha de análise psico-empírica da fenomenologia dos sentimentos dos indivíduos (do seu modo 
de sentir), desenvolvida sobretudo pelos pensadores ingleses e escoceses de orientação empirista (David Hume, Adam Smith); e uma linha de orientação mais técnica de reflexão sobre o fazer artístico e os processos da criação e produção nas diferentes artes, a que se poderia chamar a filosofia das artes (da Pintura, da Arquitectura, da Música, da Poesia, da Retórica...), um género que tem por mais antigos paradigmas a Poética e a Retórica de Aristóteles e que teve grande expressão a partir do Renascimento (pense-se em Leon Battista Alberti, em Leonardo da Vinci, em Francisco de Holanda, em Lomazzo, em Palladio e em tantos outros). Ao criar e autonomizar a nova disciplina, agora reconhecida na sua legitimidade entre os outros saberes filosóficos (a Metafísica, a Ética e a Lógica), Baumgarten não só reunia e dava fundamentação e consistência sistemática a reflexões e perspectivas que até então andavam dispersas, mas punha em evidência a importância das faculdades sensíveis humanas, geralmente desconsideradas a favor das faculdades intelectuais. Ele definia a nova disciplina como "ciência do conhecimento sensitivo, lógica da faculdade cognoscitiva inferior, gnoseologia inferior», por contraste com a Lógica, entendida como ciência do conhecimento racional. A sua ideia era mostrar que a sensibilidade tem uma lógica autónoma e se regula por princípios próprios, os quais não devem ser extraídos da lógica do entendimento ou da razão, mas sim da fantasia ou imaginação. ${ }^{2} \mathrm{Num}$ opúsculo publicado em 1735, o mesmo Baumgarten invocava, em abono da sua causa, a distinção feita pelos Antigos entre os aistheta e os noeta, entre as coisas que se referem à sensibilidade - os sensíveis - e as que se referem ao inteligível - os inteligíveis: a estas corresponde a Lógica, àquelas

\footnotetext{
${ }^{2}$ Alexander G. Baumgarten. Ästhetik (Latein-Deutsch). Hamburg: Felix Meiner, 2007, $\S 1$, Teil 1, p. 10. A ideia de que há uma "lógica da fantasia» ou "lógica da imaginação» (Logik der Phantasie/ Logik der Einbildungskraft) fora já avançada pelo pensador suíço Johann Jacob Breitinger, na sua obra Critische Abhandlung von der Natur, den Absichten und dem Gebrauche der Gleichnisse (Zürich, 1740), onde se lê, nas p.238-239: «Muitas vezes me ocorreu a ideia de que a imaginação, tal como o entendimento, necessita de uma certa Lógica. [...] Se as imagens dos sentidos entre si concordantes se ligam entre si, nascem na Lógica da fantasia as metáforas, tal como, na Lógica da razão, da ligação dos conceitos que se deixam pensar resultam as proposições.» [Es ist mir manchmahl in den Sinn gekommen, dass die Einbildungs-Kraft eben so wohl als der Verstand einer gewissen Logik vonnöthen habe. [...] Wenn die zusammenstimmenden < Sinnen-Bilder $>$ mit einander verbunden werden, so entstehen in der Logik der Phantasie die GleichnissBilder, wie in der Vernunft-Lehre aus der Verknüpfung der Begriffe, die sich gedencken lassen, die Sätze hervorwachsen.] Veja-se: Horst-Michael Schmidt. Sinnlichkeit und Verstand. Zur philosophischen und poetologischen Begründung von Erfahrung und Urteil in der deutschen Aufklärung (Leibniz,. Wolff, Gottsched, Bodmer und Breitinger, Baumgarten). München: Wilhelm Fink, 1982, pp.140 ss.
} 
corresponde a episteme aisthetike, a Estética. ${ }^{3}$ Não se pode subestimar a importância da instituição da Estética como disciplina filosófica, por parte de Baumgarten. O resultado desse acontecimento pode ver-se tanto no reconhecimento do significado desse campo de problemas e de vivências, agora apreciados em toda a sua dignidade e importância filosófica, quanto no efeito que isso viria a ter na transformação da própria ideia de filosofia. Esta deixará de medir-se preferentemente com a Matese e a Geometria, como sendo os seus paradigmas de cientificidade (assim o fora desde o século anterior, com Descartes, Hobbes, Espinosa, Leibniz...), e passará a medir-se antes pela Poesia e pela Arte, como se fossem o seu organon e a conceber-se ela mesma como sendo obra não do trabalho mecânico do entendimento segundo regras determinadas, mas como criação e desenvolvimento espontâneos do "génio da razão» (Vernunftgenius). ${ }^{4}$ O próprio Baumgarten, no citado opúsculo de 1735, propunha-se «mostrar o íntimo parentesco que existe entre a filosofia e a ciência poética». ${ }^{5}$ Tal intuito será consumado, no final do século, pelo reconhecimento de que a Poesia - compreendida como o nome colectivo das Artes - é o arche e o telos da filosofia. ${ }^{6}$ Essa consumação traduz-se não já apenas no reconhecimento de que a Estética é um domínio filosófico autónomo, ao lado da Metafísica, da Lógica, da Filosofia Natural e da Moral, mas que ela é o centro de onde irradiam e para onde tendem todas as superiores realizações do espírito e que, em suma, "O supremo acto da razão é um acto estético", como o diziam, em 1796, num seu programa filosófico comum, três jovens pensadores que viriam a ser famosos e dão pelos nomes de Hölderlin, Schelling

${ }^{3}$ A. G. Baumgarten. Meditationes philosophicae de nonnullis ad poema pertinentibus (Latein-Deutsch). Trad. e introd. de H. Paetzold. Hamburg: Felix Meiner, 1983, § 96 (p. 8486): «graeci iam philosophi et patres inter aistheta et noetá sedulo simper distinxerunt [...] Sint ergo noetá cognoscenda facultate superiore obiectum Logices; aisthetá, epistémes aisthetikés, sive AESTHETICAE.» Na Introdução à Estética Transcendental da Crítica da Razão Pura, Kant invoca essa mesma antiga distinção entre os noetá e os aisthetiká, mas, segundo tudo indica, sem conhecer essa passagem do opúsculo do seu antecessor.

${ }^{4}$ É bem significativo que seja Kant a registar isso, e fá-lo em várias ocasiões, de que dou exemplos: Welches sind die Fortschritte, Ak XX, 343: «Die Philosophie ist hier gleich als Vernunftgenius anzusehen.»; Refl. z. Logik, Ak XVI, 65:«Zu Künsten und Nachahmungswissenschaften gehört Gelehrtigkeit, zur Philosophie Genie.»; Opus postumum, Ak XXI, 141: «Mathematik ist eine Art von Gewerbzweig, (Handwerk) reine Philosophie ein Genieproduct.» Salvo indicação em contrário, os escritos de Kant são citados pela edição dos Kants gesammelte Schriften (Akademie-Ausgabe: Ak), Berlin, 1902 ss (reimpressão: Berlin: Walter de Gruyter).

${ }^{5}$ "Philosophiam et poematis pangendi scientiam, habitas saepe pro dissitissimis, amicissimo iunctas ponerem ob oculos.n Meditationes philosophicae de nonnulis ad poema pertinentibus, 1735

${ }^{6}$ F. W. J. Schelling, System des transcendentalen Idealismus (1800), Schellings Werke, ed. M. Schröter, München: Beck'sche Verlagsbuchhandlung, 1927 ss, Bd. II, p. 349-351;625629. 
e Hegel. ${ }^{7}$ Pode tomar-se esse extraordinário e fecundo momento como o da sagração da Estética e da Arte enquanto formas qualificadas de expressão e manifestação do Absoluto para a consciência moderna. Todavia, apesar da importância decisiva da realização de Baumgarten, não só para o pensamento estético, em particular, mas, em geral, também para o pensamento filosófico, Kant não irá reconhecer grande pertinência nem no título escolhido para a obra do professor de Halle, nem no propósito da mesma. É assim que, na Crítica da Razão Pura, invocando aquela mesma distinção dos Antigos entre os sensíveis (aistheta) e os inteligíveis (noeta), que Baumgarten também havia mencionado para justificar o nome da nova disicplina filosófica, Kant opta por chamar «Estética transcendental» (transcendentale Ästhetik) à primeira secção da Primeira Parte da sua obra, entendendo por tal a "doutrina da sensibilidade», isto é, a doutrina das formas a priori da sensibilidade, mas enquanto estas intervêm, subsumidas pelas categorias do entendimento, na construção do conhecimento dos objectos. Por conseguinte, numa perspectiva gnoseológica, e não psicológico-vivencial, ou enquanto se refere a uma ciência ou arte do belo pensar (ars pulchre cogitandi), que tivesse em vista o prazer ou a mera satisfação do sujeito. Por outro lado, Kant não reconhece, nesse momento, que seja possível subordinar as questões estéticas propriamente ditas a regras ou princípios a priori e elaborar uma ciência ou doutrina estética, como parece ser a pretensão de Baumgarten, pois, segundo crê - e isso tanto na $1^{\mathrm{a}}$ como ainda na $2^{\mathrm{a}}$ ed. da Crítica da Razão Pura -, os princípios do gosto ou «são meramente empíricos», ou "são-no na sua maioria», sendo empresa vã o pretender sujeitá-los a princípios racionais e propor a seu respeito uma ciência ou uma teoria. ${ }^{8}$

Hoje, podemos reconhecer que Kant não foi completamente justo para com o seu predecessor e que o terá lido e interpretado de modo parcial. De qualquer modo, Kant tinha um outro programa e que preferiu seguir uma outra tradição de reflexão sobre os problemas estéticos, a qual era representada sobretudo por alguns filósofos setecentistas ingleses (mas também franceses e até alemães), que abordavam as questões relativas aos

\footnotetext{
${ }^{7}$ O mais antigo programa de sistema do idealismo alemão. Este singular manifesto filosófico foi editado, traduzido, introduzido e anotado por Manuel José do Carmo Ferreira, in Philosophica, 9 (1997) p. 225-226.

${ }^{8}$ KrV A22/B 35; Ak IV, 30/ Ak III, 50: «Os Alemães são presentemente os únicos que se servem da palavra Estética para designar aquilo que outros chamam crítica do gosto. Reside na base disso uma falhada esperança que o notável analista abraçou de subordinar a apreciação crítica do belo a princípios racionais e de elevar as regras da mesma a uma ciência. Só que este esforço é em vão. Pois as supostas regras ou os critérios, no que respeita às suas [principais - B] fontes, são meramente empíricas e nunca podem servir para leis [determinadas - B] a priori, segundo as quais o nosso juízo de gosto se deva reger, sendo antes este último propriamente a pedra-de-toque da correcção daquelas».
} 
sentimentos estéticos (do belo e do sublime) num tipo de consideração a que chamavam expressamente "Crítica do Gosto» (Critique of Taste; Kritik des Geschmacks) ou reflexões e considerações (Beobachtungen) sobre o "gosto" ou sobre os sentimentos do belo e do sublime ${ }^{9}$, ou também «inquirições filosóficas acerca da origem das ideias do sublime e do belo». ${ }^{10}$

A noção de "gosto», sobre a qual e em torno da qual se desenvolve uma considerável parte do pensamento estético setecentista (a par com outros tópicos como o belo, as belas-artes, o génio), era extraída, por transposição metafórica da arte culinária e gastronómica, do sentido físico do gosto - da capacidade de apreciar o paladar e o sabor dos alimentos - e era usada num sentido estético já desde o Renascimento (século XVI). ${ }^{11}$ Mas ela tinha conotações também sociais, indicando a capacidade de certos indivíduos para apreciarem e pronunciarem o seu juízo acerca do que, num determinado domínio, se considerava como sendo pertinente ou como tendo gosto, assim se constituindo como críticos do gosto e juízes do "gosto são» ou do "bom gosto», seja na convivência e trato de sociedade, seja nas artes, seja até nas ciências e na filosofia. Foi tal a difusão dessa categoria no século XVIII, quer no contexto da vida de sociedade, quer no contexto propriamente estético e filosófico, que esse século mereceu os epítetos de "século do gosto» e "século da crítica». Com efeito, a noção de "crítica» - que ocorre, aliás, no título das três principais obras de Kant - desenvolveu-se e apurou-se no ambiente das reflexões sobre o gosto, como algo em que se exerce uma peculiar faculdade de apreciar ou de julgar (a gereifte Urteilskraft ou a

${ }^{9}$ Nessa linha se inscreve o ensaio de Kant de 1764, Beobachtungen über das Gefühl des Schönen und Erhabenen.

${ }^{10}$ Tal o título da obra de Edmund Burke, A Philosophical Enquiry into the Origin of our Ideas of the Sublime and Beautiful, 1757, na qual Kant largamente se inspira.

${ }^{11}$ Não deixa de ser estranho que precisamente aquele sentido que mais irredutível é à beleza e o mais impuro seja assim a base da Estética da Modernidade. Os sentidos tradicionalmente considerados como estéticos eram a vista e o ouvido, capazes, um, de captar as formas, as figuras, a luz, o brilho e as simetrias e proporções, e o outro, as harmonias (outra espécie de proporções ou relações). O próprio Rousseau, no Émile (IV), diz, do gosto, que "l'activité de ce sens est toute physique et matérielle.»

${ }^{12}$ Veja-se: Alexander von Bormann (Hrsg.). Vom Laienurteil zum Kunstgefühl. Tübingen: Max Niemeyer Verlag, 1974. Especialmente o texto de Friedrich Nicolai (1755), p. 125129: «Eine genaue und gesunde Kritik, <ist>das einzige Mittel, den guten Geschmack zu erhalten, und zu bestimmen. .. Die Hülfe der Kritik ist uns nur desto unentbehrlicher, da wir anfangen müssen, die feinen Schönheiten zu erreichen, und die feinen Fehler zu vermeiden, die nicht, gleich den gröbern, sogleich in die Sinne fallen, und auf die wir bisher zu wenig Acht gegeben haben. ... Die Kritik ist die einzige Helferin, die, indem sie unsere Unvollkommenheiten aufdeckt, in uns zugleich die Begierde nach höhern Vollkommenheiten anfachen kan.» 
reflektierende Urteilskraft). ${ }^{12}$ Um dos méritos de Kant foi, como o reconheceu Hannah Arendt, precisamente o ter posto em relevo a importância dessa faculdade - o juízo ou faculdade de julgar -, que até à época era reconhecida apenas pela sua função lógica, enquanto subordinada ao entendimento e reduzida ao serviço da aplicação dos conceitos deste aos casos particulares. E deve dizer-se que, como o próprio confessa, foi reflectindo sobre os problemas estéticos e procurando os princípios do juízo de gosto, que Kant chegou à descoberta da nova e importantíssima função dessa faculdade de julgar, função que passou a designar por reflexionante, uma função sem intenção objectivante, mas meramente subjectiva, na qual o sujeito reflecte sobre o seu próprio processo de representação e percebe o que nesse processo está envolvido, nomeadamente, como nisso se relacionam em espontânea harmonia, as suas diferentes faculdades; função enfim a que atribui a invenção e a descoberta de sentido ou de pertinência (princípio ou regra) para aquilo que, sendo dado contingentemente como singular e avulso, não cai dentro de nenhum conceito ou regra dados ou conhecidos de antemão. E nisso cabe não só a invenção nas artes como a invenção do novo, nas ciências.

Foi efectivamente como uma Kritik des Geschmacks, que, durante vários anos, foi anunciada e até parcialmente elaborada aquela obra que só muito tardiamente (menos de um ano antes de ser publicada) viria a chamarse a Kritik der Urteilskraft, em cuja nova arquitectura a "Crítica do juízo estético» (Kritik der ästhetischen Urteilskraft» ou do «juízo de gosto» (Geschmacksurteils) acabará por constituir apenas uma das duas partes. Na Primeira Introdução que escreveu para a obra de 1790, encontramos reiterada e explicada a recusa da designação «Estética» para a primeira parte da obra, ao mesmo tempo que é explicitado o sentido em que se faz uso do adjectivo "estético» para designar uma modalidade peculiar de juízo, o «juízo estético», sempre entendido como sinónimo de "juízo de gosto»: "O gosto é o poder de apreciação do belo» (Geschmack... das Vermögen der Beurteilung des Schönen sei). ${ }^{13}$

${ }^{13} \mathrm{KU}$,§ 1, Ak V, 203; Erste Einleitung in die Kritik der Urtelskraft, xi (ed. Lehmann, 56): "Wir werden die Kritik dieses Vermögens in Ansehung der ersteren Art Urteile [ästhetische Urteile] nicht Ästhetik (gleichsam Sinnenlehre), sondern Kritik der ästhetischen Urteilskraft nennen, weil der erstere Ausdruck von zu weitläufiger Bedeutung ist, indem er auch die Sinnlichkeit der Anschauung, die zum theoretischen Erkenntnis gehört und zu logischen (objektiven) Urteilen den Stoff hergibt, bedeuten könnte, daher wir auch schon den Ausdruck Ästhetik aussschliessungsweise für das Prädikat, was in Erkenntnisurteilen zur Anschauung gehört, bestimmt haben. Eine Urteilskraft aber ästhetisch zu nennen, darum, weil sie die Vorstellung eines Objekts nicht auf Begriffe und das Urteil also nicht aufs Erkenntnis bezieht (gar nicht bestimmend, sondern nur reflektierend ist), das lässt keine Missdeutung besorgen; denn für die logische Urteilskraft müssen Anschauungen, ob sie gleich sinnlich (ästhetisch) sind, dennoch zuvor zu Begriffen erhoben werden, um zum Erkenntnisse des Objekts zu dienen, welches bei der ästhetischen Urteilskraft nicht der Fall ist. 
Não sendo aqui o lugar para analisar e discutir tudo o que está em causa na dissensão de Kant relativamente a Baumgarten (e, ainda menos, para assinalar as ambiguidades que subsistem na própria utilização que Kant faz do termo «estético», no conjunto das suas obras) ${ }^{14}$, o que importa é tentar compreender o que tal desacordo revela quanto à novidade do programa filosófico kantiano, no que concerne à abordagem dos problemas estéticos. E o que de imediato salta à vista é a intenção do filósofo crítico de libertar o enfoque das questões estéticas dos pressupostos metafísicoobjectivos e intelectualistas da tradição racionalista, segundo os quais a beleza é considerada como um atributo da realidade ou de algumas realidades, e é na medida em que conhece esse atributo que o indivíduo pode pronunciar um juízo estético a respeito da beleza, um juízo que, por isso mesmo, também pode ser universalmente reconhecido por todos os indivíduos. Entretanto, sendo assim, não se vê o que distinguiria um juízo estético dum juízo de conhecimento e a pretendida autonomização da Estética ficaria comprometida.

Será que, ao recusar o racionalismo estético da escola leibnizianowolffiana, o filósofo crítico fica à mercê do empirismo e do subjectivismo, incapaz de livrar-se do completo relativismo ou da mera arbitrariedade em questões de gosto?

Para Kant, a vivência estética é propriamente a vivência de um indivíduo, é uma vivência radicalmente subjectiva. E isto quer dizer que nela não se tem em vista nada que contribua para o conhecimento do objecto enquanto tal. Este vai ser mesmo um dos novos sentidos que ele dá à noção de estético, que define, logo no $1^{\circ}$ parágrafo da obra, que leva o título «o juízo de gosto é estético»: o adjectivo "estético» não indica aqui qualidade nenhuma no objecto, mas um modo de o sujeito ser afectado quando representa ou contempla um objecto. "Estético» designa uma determinação do sujeito (um modo de ele ser afectado) e não uma determinação do objecto. Escreve Kant:

Para distinguir se algo é belo ou não, referimos a representação não através do entendimento ao objecto [Objekt] com vista ao conhecimento, mas mediante a imaginação ao sujeito e ao seu sentimento de prazer ou desprazer. O juízo de gosto não é, pois, nenhum juízo de conhecimento, por conseguinte, não é lógico mas estético, pelo que se entende aquilo cujo fundamento de determinação não pode ser senão subjectivo [nicht anders als subjektiv]. Toda a referência [Beziehung] das representações, mesmo a das sensações

\footnotetext{
$\overline{{ }^{14} \text { Kant continuará a usar o }}$ adjectivo «estético» no sentido do que se refere ao intuitivo e sensível, como oposto ao lógico (discursivo, intelectual). Sobre isso, veja-se o meu ensaio: «O estatuto da sensibilidade no pensamento kantiano: Lógica e Poética do pensamento sensível». In: RIBEIRO DOS SANTOS, 1994, p. 13-37.
} 
[Empfindungen], pode, porém, ser objectiva (ela significa nesse caso o real de uma representação empírica); só não pode sê-lo a referência ao sentimento de prazer e desprazer, mediante o qual não é designado absolutamente nada no objecto [Objekt], mas no qual o sujeito sente-se a si próprio [sich selbst fühlt] do modo como é afectado [affiziert wird] pela representação.

\section{E logo explicita com um exemplo:}

Apreender pela sua faculdade de conhecimento um edifício regular teleoforme [zweckmässiges], seja numa forma de representação clara ou confusa, é algo completamente diferente do que estar consciente desta representação com a sensação de satisfação [mit der Empfindung des Wohlgefallens]. Aqui a representação é referida inteiramente ao sujeito e, mais precisamente, ao seu sentimento vital [Lebensgefühl desselben: sentimento de vida, sentimento de estar vivo], sob o nome de sentimento de prazer ou desprazer; o qual funda um muito peculiar poder de discernir e de julgar que em nada contribui para o conhecimento, mas simplesmente confronta a representação dada no sujeito com todo o poder das representações, do qual o espírito [Gemüt] se torna consciente no sentimento do seu estado [dessen sich das Gemüt im Gefühl seines Zustandes bewusst wird].

Kant conclui:

Representações dadas num juízo podem ser empíricas (por conseguinte, estéticas), mas o juízo que é proferido através delas é lógico, se no juízo elas são referidas apenas ao objecto [Objekt]. Inversamente, porém, mesmo se as representações dadas fossem completamente racionais [gar rational], caso num juízo elas fossem referidas simplesmente ao sujeito (ao seu sentimento [sein Gefühl]), elas seriam sempre enquanto tais estéticas [so sind sie sofern jederzeit ästhetisch].

Ou seja, não é o facto de uma representação ser sensível o que a torna estética (no novo sentido do termo que lhe dá Kant), pois o sensível das intuições pode servir como matéria para os conceitos do entendimento, por conseguinte, para o conhecimento dos objectos. Mas, por outro lado, também não é o facto de as representações serem intelectuais o que as impede de serem estéticas, no novo sentido que Kant dá ao termo, pois elas podem ainda assim ser referidas apenas ao sentimento do sujeito e, por conseguinte, ser estéticas, para além do que possam representar também como conhecimento objectivo.

O primeiro parágrafo da obra, apesar de aparentemente pouco claro, é todavia de importância decisiva, pois ele divide dois regimes de pensamento estético. Um, caracterizado como o que se refere ao que é sensível por sua 
natureza e se apreende na sensibilidade; por conseguinte, ainda remetido à exterioridade e ao mundo dos objectos e das suas qualidades sensíveis. Era desse mundo sensível (de objectos com qualidades sensíveis) e apreendido na sensibilidade ou pelos sentidos do homem que sobretudo tratava a Estética de Baumgarten e, da mesma forma, muitas das doutrinas estéticas setecentistas, inclusivamente as de inspiração empirista e sensualista.

O novo regime do estético de que se ocupa a "Crítica do juízo estético», porém, não trata já propriamente da sensibilidade (Sinnlichkeit e ainda menos da Sinnenlehre), mas do sentimento (Gefühl), isto é da capacidade de o sujeito ser afectado (é isso que é dito pela expressão Empfindung) ${ }^{15}$ em si mesmo e no seu íntimo, da sua vivência enquanto tal, tenha esta por ocasião ou motivo uma representação sensível, ou uma representação intelectual. ${ }^{16}$ É o modo subjectivo da vivência, não o seu conteúdo objectivo (seja ele sensível ou intelectual), o que decide da sua qualidade ou condição estética. Pelo novo sentido que atribui ao estético, Kant abre as portas ao Romantismo. O novo sentido do "estético» - aparentemente sem objecto e sem ser por este determinado - ganha uma amplitude que o torna capaz de acontecer a propósito de qualquer objecto ou de qualquer representação, seja ela de ordem sensitiva, intelectual ou moral. Sem que as constitua enquanto tais ou para elas contribua minimamente, a dimensão estética pode todavia acompanhar tanto uma representação teórica da natureza como uma atitude moral.

\footnotetext{
${ }^{15}$ Empfindung tem no uso que Kant faz do termo um significado muito amplo. Tanto pode dizer a sensação, como o sentir, como o sentimento. Aponta mais frequentemente para o aspecto material da percepção, mas pode indicar também a dimensão subjectiva - a capacidade de o sujeito ser intimamente afectado e o modo de o ser. Veja-se: Takeshi Nakazawa. Kants Begriff der Sinnlichkeit. Seine Unterscheidung zwischen apriorischen und aposteriorischen Elementen der sinnlichen Erkenntnis und derren lateinische Vorlagen, Stuttgart-Bad Cannstatt: Frommann-Holzboog, 2009, p. 145-152.

${ }^{16} \mathrm{KU}$, Ak V, 277: «Es ist auch nicht zu läugnen, dass alle Vorstellungen in uns, sie mögen objectiv bloss sinnlich, oder ganz intellectuell sein, doch subjectiv mit Vergnügen oder Schmerz, so unmerklich beides auch sein mag, verbunden werden können (weil sie insgesammt das Gefühl des Lebens afficiren, und keine derselbe, sofern als sie Modifikation des Subjects ist, indifferent sein kann); sogar dass, wie Epikur behauptete, immer Vergnügen und Schmerz zuletzt doch körperlich sei, es mag von der Einbildung, oder gar von Verstandesvorstellungen anfangen: weil das Leben ohne das Gefühl des körperlichen Organs bloss Bewusstsein seiner Existenz, aber kein Gefühl des Wohl-oder Übelbefindens, d.i. der Beförderung oder Hemmung der Lebenskräfte, sei; weil das Gemüth für sich allein ganz Leben (das Lebensprincip selbst) ist, und Hindernisse oder Beförderungen ausser demselben und doch im Menschen selbst, mithin in der Verbindung mit seinem Körper gesucht werden müssen.l
} 
Ao longo da sua obra, Kant assinala ou sugere muitas vezes o parentesco que existe entre o sentimento estético da beleza da natureza e a contemplação teleológica da natureza (que, na verdade, é feita com base em representações do entendimento), a invenção científica ou a descoberta das leis empíricas da natureza, a vivência moral e até a experiência religiosa, sem que, todavia, aquele sentimento perca com isso a sua especificidade ou veja ferida a sua autonomia.

Kant radicaliza assim a dimensão subjectiva da experiência estética e consagra mesmo aquilo a que Hans-Georg Gadamer chamou a «subjectivação da estética» ${ }^{17}$ : o estético não é uma qualidade ou atributo dos objectos (sejam eles produtos da natureza ou produtos da arte humana), mas sim um determinado investimento humano subjectivo - um determinado modo de o sujeito ser afectado no seu sentimento vital (Lebensgefühl) - por ocasião embora da apreensão ou contemplação de um objecto. O filósofo vai mesmo ao ponto de declarar que «a beleza é algo que vale apenas para os homens, mas não enquanto seres racionais ou espirituais, mas sim enquanto seres dotados de uma natureza que é animal (sensível) e ao mesmo tempo racional $\|^{18}$. De onde se poderia concluir que os puros espíritos e o próprio Deus não são capazes nem de sentimentos estéticos nem de saborear a beleza, pois a esse sentimento e a essa ideia está associada uma capacidade de ser afectado, que indica uma limitação ou falta, o que não é concebível em seres perfeitos; no fundo, a gratificação da beleza revela a existência de uma carência e é do preenchimeno dessa carência que resulta o prazer, a satisfação; ou, então, ela indica um excesso, algo que vem por acréscimo, que não estava previsto segundo uma ordem de necessidade, mas sobrevém de forma contingente, como algo que é graciosamente dado e como tal também é acolhido; não, porém, como algo que se espere como tendo que acontecer. Kant fala a propósito de um Gunst der Natur, de um favor que natureza nos faz.

Característica da concepção kantiana do juízo estético é que ele obedeça a certos requisitos: que seja desinteressado (ohne alles Interesse: pelo que se distingue do agradável e do moralmente bom); que o agrado que suscita não seja determinado por um conceito do objecto, isto é, por um conhecimento enquanto tal; que tenha por fundamento apenas a "forma da teleoformidade» (Form der Zweckmässigkeit) de um objecto ou da representação de um objecto (e não vise a satisfação de uma utilidade ou de um objectivo determinado, nem decorra de uma qualquer ideia da função ou da perfeição do objecto ou do que ele deva ser). Assim, a beleza é descrita como sendo "a forma da

\footnotetext{
${ }^{17}$ Wahrheit und Methode. 4. ed. Tübingen: Mohr, 1975.

${ }^{18}$ «Schönheit nur für Menschen, d. i. tierische, aber doch vernünftige Wesen, aber doch nicht bloss als solche (z. B. Geister), sondern zugleich als tierische.» KU §5, Ak V, 210.
} 
teleoformidade < da confomidade a um fim $>$ de um objecto, na medida em que ela é percepcionada sem a representação de um fim». ${ }^{19}$

Mas o que é isso da «forma da teleoformidade de um objecto» que é percepcionada sem a representação de um fim?

Este tópico é importante, pois é aquele que parece permitir identificar algo que transcende a dimensão subjectiva e encontrar no objecto do juízo de gosto o que lhe serve de fundamento. Esse algo é dito mediante um oxímoro, género de expressão muito ao gosto dos escritores da época do barroco e frequente também em Kant, sobretudo nessa obra (Zweckmässigkeit < der Form > ohne Zweck - uma teleoformidade sem fim da forma). ${ }^{20} \mathrm{Um}$ exemplo pode tornar mais compreensível o que o filósofo quer dizer com esta estranha expressão, que representa o que se poderia chamar um curto-circuito da linguagem, isto é, uma autocontradição ou autoanulação no discurso, pois que afirma e nega ao mesmo tempo o que afirma. Escreve Kant:

19 «Schönheit ist Form der Zweckmässigkeit eines Gegenstandes, sofern sie ohne Vorstellung eines Zwecks an ihm wahrgenommen ist». Ak V, 236. Como traduzir a expressão alemã Zweckmässigkeit? Finalidade?, conformidade a um fim?, teleoformidade? Temos adoptado esta última solução, pois nos parece inadequada a primeira e para evitar o circunlóquio da segunda.

${ }^{20}$ São do género várias expressões usadas por Nicolau de Cusa: "douta ignorância», "altíssima profundidade», "possest»; ou a "música calada» do poeta barroco e místico espanhol San Juan de la Cruz. São também exemplos de expressões oxímoras (que se autoanulam, que dizem o mesmo e o seu contrário, provocando o paradoxo ou a perplexidade) na Crítica do Juízo: «Kunst als Natur / Natur als Kunst»; «Gesetzmässigkeit ohne Gesetz», "freie Gesetzmässigkeit» (Ak V 241): para falar do modo de produção da imaginação: "Dass die Einbildungskraft frei und doch von selbst gesetzmässig sei, d.i. dass sie eine Autonomie bei sich führe, ist ein Widerspruch. Der Verstand allein gibt das Gesetz. Wenn aber die Einbildungskraft nach einem bestimmten Gesetze zu verfahren genötigt wird, so wird ihr Produkt, der Form nach, durch Begriffe bestimmt, wie es sein soll; aber alsdann ist das Wohlgefallen, wie oben gezeigt, nicht das am Schönen, sondern am Guten (der Vollkommenheit, allenfalls bloss der formalen), und das Urteil ist kein Urteil durch Geschmack. Es wird also eine Gesetzmässigkeit ohne Gesetz, und eine subjektive Übereinstimmung der Einbildungskraft zum Verstande ohne eine objektive, da die Vorstellung auf einen bestimmten Begriff von einem Gegenstande bezogen wird, mit der freien Gesetzmässigkeit des Verstandes (welche auch Zweckmässigkeit ohne Zweck genannt worden) und mit der Eigentümlichkeit eines Geschmacksurteils allein zusammen bestehen können.» Note-se que a Gesetzmässigkeit ohne Gesetz ou a freie Gesetzmässigkeit =Zweckmässigkeit ohne Zweck, o que significa que Einbildungskraft $=$ Urteilskraft! 
Uma flor, por exemplo, uma túlipa é tida por bela, porque na percepção dela se encontra uma certa teleoformidade, a qual, na medida em que a apreciamos, não está relacionada absolutamente com nenhum fim. ${ }^{21}$

Podem o jardineiro, o botânico ou a florista virem dizer-nos que há imperfeição na floração, que a túlipa é atrofiada, que as pétalas estão irregularmente distribuídas, que precisamente aquele exemplar que nós achamos belo não tem qualquer valor comercial etc. Da mesma maneira, a percepção da beleza da túlipa não depende de sabermos para quê ela está aí, qual a sua finalidade. Para nos agradar? Para mostrar a exuberância ou a capacidade de esbanjamento da natureza? Ou as do sábio autor da natureza? -, se é que esta tem um tal autor. A túlipa, que achamos bela, tal como a rosa de Silesius, é sem porquê! Num outro passo da sua obra, Kant dirá que ela é percepcionada como algo gratuito, como se fosse um favor que a natureza (Gunst der Natur) nos faz, sem ter que fazê-lo! Apenas uma certa teleoformidade ou conveniência dos elementos num todo dado à nossa percepção é o que nela tomamos por belo. Mas uma tal conveniência ou "teleoformidade da forma" é exactamente aquilo que ao objecto ou à representação do objecto é atribuído pelo juízo reflexionante como sendo o princípio próprio desta faculdade, a saber, o princípio da teleoformidade, avançado apenas para a sua apreciação e numa intenção subjectiva, não porém como sendo de facto uma qualidade existente no objecto enquanto tal, mas apenas no sujeito que o aprecia. ${ }^{22}$ A beleza refere-se propriamente apenas à forma, não à matéria do objecto (Schönheit... die doch eigentlich bloss die Form betreffen sollte), e tem por fundamento a mera teleoformidade da forma (bloss die Zweckmässigkeit der Form zum Bestimmungsgrunde hat), como se lê no § 13. Kant insiste neste ponto. Assim, no § 11:

O juízo de gosto não tem por fundamento outra coisa senão a forma da teleoformidade de um objecto (ou do modo da representação deste objecto). [...] Por conseguinte, é apenas a teleoformidade subjectiva na representação de um objecto, sem qualquer fim (nem objectivo nem subjectivo), por conseguinte, a simples forma da teleoformidade na representação mediante

\footnotetext{
21 «Eine Blume, z.B. eine Tulpe, wird für schön gehalten, weil eine gewisse Zweckmässigkeit, die so, wie wir sie beurteilen, auf gar keinen Zweck bezogen wird, in ihrer Wahrnehmung angetroffen wird.» Ak V, 236.

22 «Dieser transzendentaler Begriff einer Zweckmässigkeit der Natur... gar nichts dem Objekte (der Natur) beilegt, sondern nur die einzige Art, wie wir in der Reflexion über die Gegenstände der Natur [...] vorstelle, folglich ein subjektives Prinzip (Maxime) der Urteilskraft; daher wir auch, gleich als ob es ein glücklicher unsre Absicht begünstigender Zufall wäre, erfreuet [...] werden.» Einl.,V. KU, Ak V,
} 
a qual um objecto nos é dado, o que constitui a satisfação que, sem qualquer conceito, nós julgamos como universalmente comunicável e, por conseguinte, como o princípio determinante do juízo de gosto. ${ }^{23}$

\section{E no § 12:}

A consciência da teleoformidade meramente formal no jogo das faculdades de conhecimento do sujeito, por ocasião de uma representação, mediante a qual um objecto nos é dado, é o próprio prazer, porque ela contém um princípio determinante da actividade do sujeito com vista à dinamização das suas faculdades de conhecimento do mesmo, por conseguinte, uma causalidade interna (que é teleoforme) [...] uma simples forma da teleoformidade subjectiva de uma representação num juízo estético. ${ }^{24}$

De acordo com tal pressuposto, não há objectos que são estéticos por si e outros que o não são; já que, em qualquer um, pode um sujeito descobrir a teleoformidade de uma forma que o torna para ele ocasião de um juízo ou sentimento estético. Pense-se, por exemplo, no quadro de Van Gogh «Sapatos velhos com atilhos». Nada recomendaria aqueles objectos como belos, nem sequer como dignos da atenção e muito menos para um juízo estético ou sequer como matéria para o pintor. Deixá-los-íamos à porta da rua para que os recolhedores do lixo os levassem para a lixeira, pois - assim velhos, gastos, rotos, deformados, sujos - já nem préstimo para o uso de um pedinte têm. Muito menos nos ocorreria a ideia de os levar para os entronizar como um objecto de contemplação numa das salas da nossa casa. Todavia, ao caírem sob o olhar do pintor ou do artista, eles são, por assim dizer, transfigurados por esse olhar e logo também pela sua arte, revelando, tanto para o artista, quanto para os que venham a contemplá-los, uma qualidade estética - isto

${ }^{23}$ "Das Geschmacksurteil hat nichts als die Form der Zweckmässigkeit eines Gegenstandes (oder der Vorstellungsart desselben) zum Grunde.[...] Also kann nichts anders als die subjektive Zweckmässigkeit in der Vorstellung eines Gegenstandes, ohne allen (weder objektiven noch subjektiven) Zweck, folglich die blosse Form der Zweckmässigkeit in der Vorstellung, wodur uns ein Gegenstand gegeben wird, sofern wir uns ihrer bewusst sind, das Wohlgefallen, welches wir ohne Begriff, als allgemeine mitteilbar beurteilen, mithin den Bestimmungsgrund des Geschmacksurteils, ausmachen.» $\mathrm{KU} \S 11$.

${ }^{24}$ «Das Bewusstsein der bloss formalen Zweckmässigkeit im Spiele der Erkenntniskräfte des Subjekts, bei einer Vorstellung, wodurch ein Gegenstand gegeben wird, ist die Lus selbst, weil es einen Bestimmungsgrund der Tätigkeit des Subjekts in Ansehung der Belebung der Erkenntniskräfte desselben, also eine innere Kausalität (welche zweckmässig ist) in Ansehung der Erkenntnis überhaupt, aber ohne auf eine bestimmte Erkenntnis eingeschränkt zu sein, mithin eine blosse Form der subjektiven Zweckmässigkeit einer Vorstellung in einem ästhetischen Urteile enthält.» KU § 12. 
é, a capacidade de suscitarem ou darem ocasião para um sentimento -, a qual, todavia, lhes é conferida apenas pela intencionalidade subjectiva de quem os pinta ou os contempla. É o olhar - do pintor e do contemplador que os transfigura esteticamente. ${ }^{25}$ Isso foi dito com simplicidade e acerto pelas palavras de um poeta, o heterónimo de Fernando Pessoa que dá pelo nome de Alberto Caeiro:

A belleza é o nome de qualquer cousa que não existe

Que eu dou às cousas em troca do agrado que me dão. ${ }^{26}$

Por conseguinte, pode dizer-se que, ao limite, qualquer objecto pode ser ocasião para uma experiência estética ou vir a ser transfigurado por ela. É isso o que Kant designa por idealismo estético: não o pensar que o mundo é belo, ou que há no mundo coisas belas, mas o dispôr o espírito para transfigurar esteticamente e embelezar o mundo. Foi isso que os Românticos radicalizaram com o seu projecto de "romantizar o mundo», segundo o conhecido lema de Novalis - "Die Welt muss romantisiert werden» compreendendo o mundo como um universal tropo - símbolo ou metáfora do espírito humano e dos respectivos sentimentos.

É na doutrina kantiana do juízo estético que se afirma de modo mais extremo a autonomia da subjectividade, não só enquanto espontaneidade criadora de formas, mas também enquanto poder de reflexão "heautonómica», sobre si própria e para si própria. Aquilo que na contemplação do objecto estético produz satisfação é a forma que o espírito nele vê reflectida, mas como algo que pelo mesmo sujeito é atribuído ao objecto, sem outro intuito que não seja o da sua «mera contemplação» e fruição desinteressada. Tal

\footnotetext{
${ }^{25}$ O mesmo se poderia dizer do famoso urinol de Duchamp, resgatado da sua muito útil mas baixa e vil função e, uma vez rebaptizado como "Fonte», vê-se sublimado esteticamente, tornando-se um nobre objecto estético, não tanto, talvez, para uma mera contemplação desinteressada quanto, muito mais, para sobejas dissertações e discussões acaloradas acerca da natureza e estranho destino da arte contemporânea! (Veja-se: T. de Duve. Kant nach Duchamp. München: Boer, 1993). Por muito que tal nos pareça algo contra-natura, Kant ver-se-ia assim, não ultrapassado e negado, mas antes promovido a verdadeiro patrocinador intelectual de toda a arte do modernismo e até do pós-modernismo (J-F.Lyotard. Leçons sur l'Analytique du Sublime. Paris: Galilée, 1991; L'inhumain. Causeries sur le temps. Paris : Galilée, 1988 («Le sublime et l'avant-garde»). Deve, todavia, ter-se em conta que Kant dispunha de contrapesos à arbitrariedade instituinte do artista que os modernistas e pós-modernistas já não têm. Tais contrapesos eram a natureza, o sentido comum e, em última instância, uma visão moral do mundo, a qual no fundo envolve toda a concepção kantiana das questões estéticas.

${ }^{26}$ PESSOA, Fernando. Poemas completos de Alberto Caeiro. Ed. de Teresa Sobral Cunha. Lisboa: Presença, 1994. p. 76.
} 
forma - a «teleoformidade da forma» - outra coisa não é, porém, senão o efeito do jogo espontâneo e harmónico das diferentes faculdades do espírito (imaginação e entendimento), experimentado pelo próprio sujeito no acto de reflexão que faz sobre si próprio quando contempla um objecto que lhe é dado. É como se o objecto da contemplação ficasse entre parênteses e não fosse visado enquanto tal. E, todavia, é desse modo que ele ganha a sua autonomia e até transcendência, deixando de ser encarado como algo meramente útil, usável e consumível no circuito dos interesses ou das necessidades. Sendo a experiência da máxima autonomia e dignidade do sujeito, a experiência estética é também a revelação máxima da dignidade do objecto, que assim é transfigurado e instituído como algo absoluto e válido por si mesmo, como um objecto para a pura contemplação. A partir de Kant, e depois de Kant, a vivência estética torna-se, para a consciência moderna, o análogo e até mesmo o sucedâneo de uma vivência religiosa, que garante o acesso a um domínio onde, num mundo cada vez mais secularizado, ainda subsiste alguma memória do absoluto e do sagrado. E a própria arte ver-seá instituída como o último grande mito do homem, onde este se reconhece como livre criador de um mundo de objectos e de significações propriamente humanas que desafiam o tempo. ${ }^{27}$

O juízo estético - nomeadamente o do belo da natureza - é a experiência de um feliz encontro e de um espontâneo acordo entre a «forma da teleoformidade» (do sujeito) e a "teleoformidade da forma» (do objecto) que nos é dado na aparição singular deste. O objecto não é, propriamente falando, a causa do sentimento estético. Para dizer o tipo de acção do objecto sobre o sujeito que desencadeia a reflexão em que consiste a experiência estética, Kant usa termos como "suscitar», «despertar», "ser ocasião de». De modo algum, porém, se pode concluir que pode haver experiência estética sem objecto (Gegenstand) real, representado ou ideal. Kant não sancionaria um intimismo estético que trabalhasse no vácuo. Porém, o facto de fazer consistir a essência do juízo estético na percepção da "teleoformidade da forma» do objecto que o suscita coloca-o perante uma dificuldade, pois isso vale para o sentimento do belo, mas parece ser totalmente contrariado pelo sentimento do sublime. Se a experiência do belo da natureza é a gratificante experiência da harmonia das faculdades (imaginação e entendimento) no seu livre jogo, o espontâneo acordo da forma da teleoformidade do objecto com a teleoformidade da forma do sujeito, que nos faz sentir em originária

${ }^{27} \mathrm{O}$ escritor, ensaísta e pensador português Vergílio Ferreira viu isso com particular lucidez, na sua obra Invocação ao meu corpo. Lisboa: Bertrand, 1969. Veja-se, a propósito, o meu ensaio "A arte como obsessão, ou o humanismo estético de Vergílio Ferreira», no meu livro Melancolia e Apocalipse. Estudos sobre o Pensamento Português e Brasileiro. Lisboa: Imprensa Nacional-Casa da Moeda, 2008. p. 349-374. 
sintonia com a natureza (o objecto), a qual se entrega à nossa representação como se tivesse sido feita para nós e nós para ela, já a experiência do sublime da natureza, pelo contrário, coloca-nos perante certas manifestações que revelam a natureza como sendo em si mesma desprovida de qualquer teleoformidade, entregue à mercê de forças caóticas, descontroladas e destruidoras, que não só ofendem a nossa sensibilidade como são mesmo irredutíveis à apreensão pelas nossas capacidades de representação, apresentando-se como algo informe (formlos) e irredutível a qualquer forma, seja pela sua desmedida grandeza, seja pelo seu desmedido poder. Por isso, o sentimento do sublime é mais um sentimento de desprazer do que de prazer, ou é um sentimento de prazer negativo, que põe de manifesto a inadequação da imaginação humana para apreender e representar a natureza na sua incomensurabilidade e poder. Mas é precisamente nessa violência que a natureza - enquanto objecto de um sentimento do sublime - exerce sobre a nossa imaginação e na inadequação desta para captar a natureza numa forma que, segundo Kant, se revela uma superior teleoformidade, não já da natureza, mas do sistema das faculdades espirituais do homem, que impele a imaginação a relacionar-se não com o entendimento no âmbito da natureza, mas com a razão e as suas ideias morais, no âmbito da destinação suprasensível do homem. O sentimento do sublime revela assim, esteticamente, isto é, na própria sensibilidade e no sentimento - (Kant fala aqui de comoção do ânimo - um abalo que nos atinge totalmente - e não de mera contemplação tranquila, como no caso do belo) - que a condição do homem não se cumpre no plano da natureza. Pelo sentimento do sublime, a própria natureza, mediante algumas suas manifestações de grandeza e poder, fala-nos do que está para além dela, revela-nos a nossa condição moral, oferece-se como um símbolo do absoluto e do infinito. A explicação de Kant é complexa. Ouçamo-la:

A natureza do sentimento do sublime consiste em que ele é um sentimento de desprazer num objecto, contudo representado ao mesmo tempo como conforme a fins; o que é possível pelo facto de que a falta de poder [Unvermögen] própria descobre a consciência de um poder [Vermögen] ilimitado do mesmo sujeito e o ânimo só pode ajuizar esteticamente a última através da primeira [...]. Se uma grandeza quase atinge numa intuição o extremo da nossa faculdade de compreensão e a imaginação é contudo desafiada, através de grandezas numéricas [...] à compreensão estética em uma unidade maior, então sentimo-nos no ânimo como que esteticamente encerrados dentro de limites; e contudo o desprazer é representado como conforme a fins com respeito à ampliação necessária da imaginação para a adequação ao que na nossa faculdade da razão é ilimitado, ou seja, a ideia do todo absoluto, por conseguinte, a ausência de finalidade [Unzweckmässigkeit] do poder da imaginação para as ideias da razão e para o despertar destas. Mas precisamente por isso o próprio juízo estético tornase subjectivamente conforme a fins [subjektiv-zweckmässig] para a razão 
como fonte das ideias, ou seja de uma compreensão [Zusammenfassung] intelectual relativamente à qual toda a compreensão estética é pequena; e o objecto é acolhido como sublime com um prazer que só é possível mediante um desprazer. ${ }^{28}$

\section{Mais claro ainda é o §28:}

Rochedos audaciosamente suspensos por cima de nós pesando como uma ameaça, nuvens de tempestade acumulando-se no céu avançando com relâmpagos e trovões, vulcões em sua inteira força destruidora, furacões deixando atrás de si a devastação, o ilimitado oceano revolto, as cataratas de um rio poderoso, etc. tornam a nossa capacidade de resistência de uma pequenez insignificante em comparação com o seu poder. Mas o seu espectáculo só se torna tanto mais atraente quanto mais terrível ele é, contanto que nos encontremos em segurança; e de bom grado denominamos estes objectos sublimes, porque eles elevam a fortaleza da alma acima de seu nível médio e permitem descobrir em nós uma faculdade de resistência de uma espécie totalmente diversa, a qual nos encoraja a medir-nos com a aparente omnipotência da natureza. Pois assim como na verdade encontramos a nossa própria limitação na incomensurabilidade da natureza e na insuficiência da nossa faculdade para tomar um padrão de medida proporcionado à avaliação estética da grandeza do seu domínio, e todavia também ao mesmo tempo encontramos em nossa faculdade da razão um outro padrão de medida não sensível, que tem sob si como unidade aquela própria infinitude e em confronto com o qual tudo na natureza é pequeno; por conseguinte, encontramos em nosso ânimo uma superioridade sobre a própria natureza em sua incomensurabilidade; assim também o carácter irresistível de seu poder dá-nos a conhecer, a nós considerados como seres da natureza, a nossa impotência física, mas descobre ao mesmo tempo uma faculdade de ajuizar-nos como independentes dela e uma superioridade sobre a natureza, sobre a qual se funda uma auto-conservação de espécie totalmente diferente daquela que pode ser atacada e posta em perigo pela natureza fora de nós, com o que a humanidade em nossa pessoa não fica rebaixada, mesmo que o homem tivesse que sucumbir àquela força. [...] Portanto, a natureza aqui chama-se sublime simplesmente porque ela eleva a faculdade da imaginação à apresentação daqueles casos nos quais o ânimo pode tornar capaz de ser sentida a sublimidade da sua destinação, mesmo acima da natureza.

A explicação parece muito rebuscada e artificial. Kant, porém, assegura que ela corresponde à observação de qualquer ser humano e que está na base

${ }^{28} \mathrm{KU}, \S 27$ 
dos juízos mais comuns, ainda que nem sempre se tenha disso consciência. Contudo, o que tal explicação expõe é todo o poder analítico de Kant, ao mesmo tempo que nela se revela o esforço do filósofo para dar conta da tensão que existe na própria condição estética do homem e para realçar a harmonia ou adequação superior - expressa pelo termo Zweckmässigkeit - e até a ampliação das forças anímicas que resulta desse conflito estético entre o sentimento do belo e do sublime. Se na experiência do belo se revelava o espontâneo acordo entre a imaginação e o entendimento, na experiência do sublime, de uma forma por certo muito mais complexa, evidencia-se, já no domínio estético e sensível, o acordo entre a imaginação e a razão enquanto faculdade das ideias e da moralidade. No conjunto, as duas experiências estéticas, aparentemente e fenomenologicamente antitéticas, põem em evidência, no plano da sensibilidade e do sentimento, a complexa harmonia do organismo do espírito. ${ }^{29}$

Mas precisamente no sentimento do sublime é ainda mais evidente o efeito da subjectivação da estética que a concepção kantiana consagra, pois o que aí se torna manifesto é que, propriamente falando,

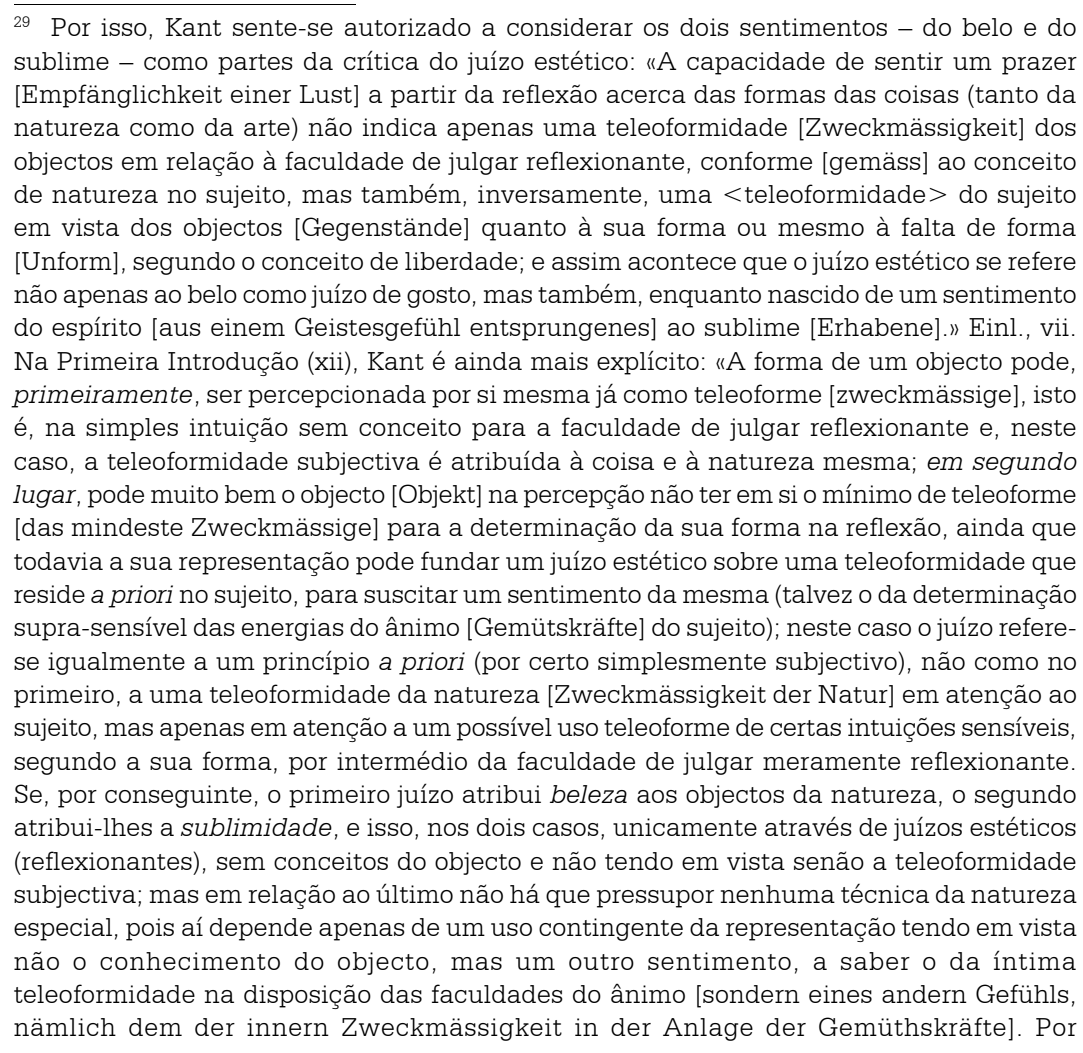




\begin{abstract}
A sublimidade não está contida em nenhuma coisa da natureza, mas só no nosso ânimo, na medida em que podemos ser conscientes de ser superiores à natureza em nós e também à natureza fora de nós... Tudo o que desperta em nós este sentimento, como é o caso da força da natureza que desafia as nossas forças, chama-se então (ainda que impropriamente) sublime; e é somente na pressuposição desta ideia em nós e em referência a ela que somos capazes de chegar à ideia da sublimidade daquele Ser que provoca em nós um profundo respeito, não apenas através da força que ele manifesta na natureza, mas ainda mais através do poder que se encontra inscrito em nós de ajuizar sem medo aquela força e pensar a nossa destinação como sublime para além dela. ${ }^{30}$
\end{abstract}

2 Que tipo de universalidade e de necessidade podem pretender os juízos estéticos?

A recusa de uma Estética fundada metafisicamente, numa ordem do ser e dos respectivos atributos ou qualidades, e a insistência na condição de subjectividade do juízo estético colocam a Kant o problema de como dar razão da peculiar necessidade e universalidade com que os juízos estéticos se apresentam, de tal modo que, quando, por exemplo, dizemos que uma rosa (ou uma paisagem) é bela, não consentimos que os outros tenham uma opinião diferente da nossa, embora não sejamos capazes de apresentar nenhuma razão objectiva para os convencermos de que devem concordar com esse nosso juízo. O que nos dá o direito a tal pretensão ou presunção? Temos ao menos o direito de esperar que a apreciação estética que nós fazemos de um objecto possa ser compartilhada por outros? Ou devemos render-nos à condição meramente privada dos nossos sentimentos e juízos estéticos? Por outras palavras: sendo o juízo estético uma vivência inalienável de um sujeito, que tipo de universalidade e de necessidade é possível reconhecer-lhe, ou de todo não é possível atribuir-lhe qualquer pretensão de universalidade e necessidade, e, ao limite, nem sequer de comunicabilidade?

Há muitos indícios que revelam que essa questão preocupou Kant durante longos anos e desde muito cedo, pelo menos desde o início dos anos 70, e que ele ensaiou diferentes maneiras de lhe dar resposta, chegando mesmo a desesperar de a encontrar. Algumas Reflexões dos primeiros anos da década de 70 (1770-1773) mostram que Kant tentou fundar uma teoria do juízo do belo e do gosto, enquanto sentimentos "válidos para todos», sobre os recém-descobertos princípios formais da sensibilidade (as intuições a priori

conseguinte, o juízo sobre o sublime na natureza não deverá ser excluído da divisão da estética da faculdade de julgar reflexionante, pois ele exprime também uma teleoformidade subjectiva que não se funda sobre um conceito do objecto» (ed. Lehmann, p. 59-61).

${ }^{30} \mathrm{KU} \S 28$, parágrafo final. 
do espaço e do tempo). A Reflexão 672, provavelmente contemporânea da redacção da Dissertação de 1770, ou pouco posterior, é particularmente significativa a este respeito. Ela diz o seguinte:

Dado que cada objecto da sensibilidade tem uma relação com o nosso estado, mesmo naquilo que pertence ao conhecimento e não à sensação [Empfindung], designadamente no confronto do múltiplo e da forma (pois este confronto afecta o nosso estado, na medida em que nos pesa ou nos é leve, em que anima ou inibe toda a nossa actividade), nessa medida existe algo em todo o conhecimento que é da ordem da agradabilidade [Annehmlichkeit]; mas, nesse caso, a aprovação [Billigung] não se refere ao objecto e a beleza não é algo que pode ser conhecido, mas apenas sentido [nur empfunden]. Aquilo que no objecto agrada e que consideramos como uma propriedade do mesmo, tem de consistir no que vale para todos [was vor iedermann gilt]. Ora as relações do espaço e do tempo valem para todos, quaisquer que sejam as sensações [Empfindungen] que se tenham. Portanto, em todos os fenómenos [Erscheinungen] a forma é universalmente válida; e esta forma é conhecida também segundo regras comuns de coordenação; por conseguinte, aquilo que é conforme à regra de coordenação no espaço e no tempo, isso agrada necessariamente a todos e é belo [was also der Regel der Coordination in Raum und Zeit gemäss ist, das gefält nothwendig iedermann und ist schön]. O agradável na intuição da beleza depende da apreensibilidade de um todo, mas a beleza depende da validade universal destas proporcionadas relações [das Angenehme in dem Anschauen der Schönheit komt an auf die Fasslichkeit eines Ganzen, allein die Schönheit auf die allgemeine Gültigkeit dieser schiklichen Verhältnisse]. ${ }^{31}$

Da mesma solução encontramos ainda vestígios no Curso de Lógica, tardiamente publicado por Jäsche (1800), onde lemos:

A perfeição estética consiste na concordância do conhecimento com o sujeito e baseia-se na sensibilidade particular do ser humano. Por isso, no caso da perfeição estética, não há lugar para leis objectivas e universalmente válidas, relativamente às quais ela se deixaria avaliar a priori de uma maneira universalmente válida para todos os seres pensantes em geral. Na medida, porém, em que também há leis universais da sensibilidade que, muito embora não tenham validade objectivamente e para todos os seres pensantes em geral, têm, contudo, subjectivamente validade para o conjunto da humanidade: é possível também pensar uma perfeição estética que contenha o fundamento de um agrado subjectivamente universal. Tal é a beleza - aquilo que agrada aos sentidos na intuição e, exactamente por isso, pode ser o objecto de um agrado universal, porque as leis da intuição são leis universais da sensibilidade. É por essa concordância com as leis universais da sensibilidade que se distingue, quanto à espécie, o belo propriamente dito, auto-subsistente, cuja essência consiste na mera forma, do aprazível, que agrada unicamente

$\overline{{ }^{31} \text { Reflexion 672, Ak XV, } 298 .}$ 
na sensação pelo encanto ou emoção e, por essa razão, só pode ser também o fundamento de um mero agrado privado. ${ }^{32}$

E é ainda na mesma linha que vão os desenvolvimentos do Curso de Lógica (Logik-Philippi), registados em maio de 1772, por um dos alunos de Kant, onde se lê:

O fundamento do comprazimento nas proposições da razão reside, se não me engano, na multiplicação das perspectivas, e a perfeição das mesmas nos produtos do gosto, na facilidade de captar uma multidão de múltiplas impressões, ordená-las sem esforço, distingui-las, senti-las com vivacidade e poder abrangê-las com a vista num todo. Como acima dissemos, as leis da nossa sensibilidade são muito concordantes com as leis da sensibilidade dos outros e disso resultam as regras fundamentais do gosto. Mas que tipo de leis são essas? A nossa sensibilidade está em constante actividade e quer estar assim constantemente. Desta lei fundamental da sensibilidade se deduz a regra do gosto: se um objecto da sensibilidade deve agradar, então deve haver nele multiplicidade, para que tenha material com o qual se possa ocupar: o espírito é activo na forma de todos os objectos. Ele fornece os materiais e quer transformá-los mediante o objecto. - Tudo o que obstaculiza esta actividade da sensibilidade, é-lhe desgostoso e desagradável. Daqui resulta a regra: esforçamo-nos por colocar no múltiplo simetria, harmonia e clareza e em geral compreensibilidade, com o que a sensibilidade possa captar o objecto sem esforço, e distinguir facilmente e sentir as impressões do mesmo. Por conseguinte, o gosto requer multiplicidade, contraste, harmonia, facilidade, clareza e uma contínua passagem de uma coisa para o seu oposto, o salto perturba a sensibilidade. Um objecto no qual tudo isto está dado numa relação compreensível, é essencialmente belo e agrada universalmente. Um grande objecto como um edifício agrada se nele houver simetria; ela facilita a contemplação do edifício. [...] Há pois certas leis comuns da sensibilidade no que respeita à forma e, se não me engano, estas são as que até agora percorri. - Só que a sensação deve ser completamente isolada. [...] Se um

\footnotetext{
${ }^{2}$ «Die ästhetische Vollkommenheit besteht in der Übereinstimmung des Erkenntnisses mit dem Subjekte, und gründet sich auf die besondre Sinnlichkeit des Menschen. Es finden daher bei der ästhetischen Vollkommenheit keine objektiv- und allgemeingültigen Gesetze statt, in Beziehung auf welche sie sich a priori auf eine für alle denkende Wesen überhaupt, doch subjektiv für die gesamte Menschheit Gültigkeit haben: lässt sich auch eine ästhetische Vollkommenheit denken, sie den Grund eines subjektiv-allgemeinen Wohlgefallens enthält. Dieses ist die Schönheit - das, was den Sinnen in der Anschauung gefällt und eben darum der Gegenstand eines allgemeinen Wohlgefallens sein kann, weil die Gesetze der Anschauung allgemeine Gesetze der Sinnlichkeit sind. Durch diese Übereinstimmung mit den allgemeinen Gesetzen der Sinnlichkeit unterscheidet sich der Art nach das eigentliche, selbständige Schöne, dessen Wesen in der blossen Form besteht, von dem Angenehmen, das lediglich in der Empfindgung durch Reiz oder Rührung gefällt, und um deswillen auch nur der Grund eines blossen Privat-Wohklgefallens sein kann.» Ak IX, 36-37.
} 
homem não sabe as leis da sensibilidade também o belo não lhe pode agradar. Pois os objectos dos sentidos têm de ser apreciados segundo as leis da sensibilidade. Um tal homem aprecia então segundo a sensação. ${ }^{33}$

A solução apresentada nas passagens anteriormente citadas parece apontar no sentido de conciliar os pressupostos de uma estética racionalista (a percepção da unidade de um múltiplo, da simetria, da harmonia, da perfeição, da clareza), com os de uma estética empirista ou sensualista, segundo o que aquela unidade e demais qualidades são percebidas não pela razão, mas pela sensibilidade mediante as intuições do espaço e do tempo. Tal como há princípios de ordem e beleza que regem o conhecimento racional, assim os há também no conhecimento sensível: à perfeição lógica corresponde uma perfeição estética. Apesar de tudo, Kant está, nessas reflexões, muito próximo da proposta baumgarteniana da Estética entendida como uma lógica da sensibilidade, mediante a qual o sujeito capta a perfeição

${ }_{33}$ «Der Grund des Wohlgefallens bei Vernunftsätzen liegt, wo ich nicht irre, in der Vermehrung der Einsichten, und Vollkommenheit derselben [-] bei Produkten des Geschmacks, in der Leichtigkeit eine Menge mannigfaltiger Eindrücke aufnehmen, sie ohne Mühe ordnen, unterscheiden, lebhaft empfinden und im Ganzen überschauen zu können. Unsere Sinnlichkeit Gesetze sagten wir oben sind mit dem Gesetzen der Sinnlichkeit anderer sehr übereinstimmend, und daraus werden die Grundregeln des Geschmacks bezogen. Was sind das für Gesetze? - Unsere Sinnlichkeit ist in beständiger Aktivität und will es auch beständig sein. Aus diesem Grundgesetz der Sinnlichkeit zieht man die Regel des Geschmacks: soll ein Objekt der Sinnlichkeit gefallen, so muss darin Mannigfaltigkeit angebracht werden, damit sie Stoff bekomme womit sie sich beschäftigen kann: Das Gemüt ist bei der Form aller Gegenstände tätig. Es gibt die Materialien her, und will sie durch den Gegenstand gebildet haben. - Alles was diese Aktivität der Sinnlichkeit hindert, ist ihr verdriesslich und unangenehm. Hieraus fliesst die Regel: man bemühe sich in dem Mannigfaltigen, Symmetrie, Harmonie und Klarheit und überhaupt Fasslichkeit anzubringen, damit die Sinnlichkeit den Gegenstand ohne Mühe fassen, die Eindrücke desselben leicht unterscheiden und empfinden kann. Also fordert der Geschmack Mannigfaltigkeit, Kontrast, Harmonie, Leichtigkeit, Klarheit und einen allmählichen Übergang von einem bis aufs Oppositum desselben, der Sprung verwirrt die Sinnlichkeit. Ein Gegenstand an dem dieses alles in einem fasslichen Verhältnis angebracht ist, ist wesentlich schön und gefällt allgemein. Ein grosser Gegenstand als ein Gebäude gefällt wenn Symmetrie darin angebracht ist; sie erleichtert den Anblick des Gebäudes. [...] Es gibt also gewisse gemeine Gesetze der Sinnlichkeit in Ansehung der Form und dieses werden, wo ich nicht irre, diejenigen sein die ich bisher durchgegangen. - Allein es muss der Reiz gans abgesondert werden. [...]]Wenn ein Mensch die Gesetze der Sinnlichkeit nicht weiss, so kann ihm auch das Schöne nicht gefallen: denn Gegenstände der Sinne müssen nach Gesetzen der Sinnlichkeit beurteilt werden; ein solcher Mensch urteilt dann nach dem Reiz.n (Logik-Philippi, Ak XXIV, Berlin, 1966, apud Jens Kulemkampf. Materialien zu Kants Kritik der Urteilskraft. Frankfurt a. Main: Suhrkamp, p. 106-107). 
do mundo sensível.

Todavia, na Crítica da Razão Pura, seja na primeira, seja na segunda edição da obra, não há qualquer vestígio de continuidade com essa linha de solução. Pelo contrário, Kant parece ter deixado definitivamente de esperar encontrar uma explicação para uma possível universalidade dos princípios do gosto, e declara mesmo expressamente que "os princípios de gosto são meramente [ou na sua maior parte, segundo a versão B] empíricos (ihren vornehmsten Quellen nach bloss empirisch)». É só numa Carta a Reinhold, de finais de dezembro de 1787, já depois de publicada a segunda edição da Crítica, que, pela primeira vez, Kant confessa ter "descoberto» um novo princípio a priori, o qual governa o sentimento de prazer e desprazer, e isso, como igualmente aí refere, depois de ter desesperado de o encontrar. E, embora na Crítica do Juízo tenha dado uma solução positiva a esse problema, o filósofo continua a referir-se a esse sentimento como estando envolvido por uma natural obscuridade ou complexidade que torna difícil a sua abordagem e a compreensão da sua verdadeira natureza, a qual no fundo, permanece um mistério não completamente revelado. ${ }^{34}$ Ao longo de toda a primeira parte da terceira Crítica, Kant enfrenta o problema em vários momentos, tentando garantir para os juízos estéticos um certo tipo de universalidade e de necessidade, a qual é, porém, radicalmente distinta da universalidade lógica e da necessidade fundada num conhecimento objectivo, não podendo, por conseguinte, ser objecto de uma demonstração mediante a invocação de determinadas qualidades ou propriedades do objecto do juízo; distinta até da universalidade imperativa e categórica, que é própria dos princípios da moralidade. Graças a esse esforço, da mesma maneira que antes o vimos superar o pressuposto do racionalismo estético, Kant tenta ultrapassar o pressuposto do empirismo e sensualismo estéticos, que inspirava a concepção de fundo de muitos pensadores de cujas obras se alimentou desde cedo a sua reflexão sobre os temas do gosto e dos sentimentos do belo e do sublime (1764: Beobachtungen über das Gefühl des Schönen und Erhabenen) a sua própria reflexão, sobretudo Edmund Burke (Philosophical Enquiry Into the Origins of Our Ideas of the Sublime

\footnotetext{
${ }^{{ }^{4}}$ Assim, no Prefácio da KU: «[...] kann die grosse Schwierigkeit, ein Problem, welches die Natur so verwickelt hat, aufzulösen, einiger nicht ganz zu vermeindenden Dunkelheit in der Auflösung desselben, wie ich hoffe, zur Entschuldigung dienen...» Também a carta a Reichardt (15 out. 1790, Ak XI,228) alude ao "so schweer zu erforschenden Geschmacksvermögen». Noutros lugares, Kant sugere que a comunicabilidade e universalidade do gosto se fundam na proximidade que esse sentimento tem com o sentimento moral. A já citada Carta a Reichardt di-lo sem ambiguidade (texto citado infra): sem sentimento moral não teríamos qualquer sentimento do belo e do sublime.
} 
and the Beautiful, 1756), mas também David Hume (Of the Standard of Taste, 1757), ${ }^{35}$ e ainda outros, como Hutcheson, Shaftesbury, Gerard, Hogarth.

Segundo o filósofo, a comunicabilidade dos juízos estéticos e a universalidade que lhes é peculiar e que nós com direito presumimos, fundase num "sentido comum" que existe em todos os seres humanos e que Kant interpreta não como um vago senso comum mas como sendo propriamente um sensus communis aestheticus, que se identifica com o próprio gosto (Geschmack) e que define como «o poder de apreciação daquilo que, numa dada representação e sem mediação de um conceito, o nosso sentimento torna universalmente comunicável». ${ }^{36}$

Por certo, essa comunicabilidade é, como vimos (§ 11), facilitada já pelo facto de que o que se comunica na experiência estética não é um prazer que se refira à matéria do objecto ou dela resulte, e sim apenas a satisfação que nasce da percepção da mera forma - «forma da teleoformidade ou teleoformidade da forma» - que o sujeito, na sua reflexão, atribui ao objecto. Desse modo, Kant pode afirmar que a necessidade do assentimento universal, pensada num juízo de gosto, é uma necessidade subjectiva, que, sob a pressuposição da existência de um sentido comum em todos os homens, é representada como objectiva. Reporta-se a esse originário sentido comum ou comunitário a capacidade de criar ou inventar uma «norma ideal mas indeterminada» do juízo de gosto, que se pressupõe existir em todos os seres humanos e que garante a comunicabilidade dos sentimentos entre eles. Assim se lê, no § 22:

Em todos os juízos mediante os quais declaramos algo belo não permitimos a ninguém que seja de outra opinião, sem com isso fundarmos o nosso juízo sobre conceitos, mas somente sobre o nosso sentimento; o qual, por conseguinte, colocamos por fundamento, não como sentimento privado, mas como um sentimento comunitário [gemeinschaftliches Gefühl] ... Assim o sentido comum [Gemeinsinn] de que dou como exemplo aqui o meu juízo de

\footnotetext{
${ }^{35}$ Segundo Hume, o que funda a pertinência do juízo de gosto e estabelece as normas do gosto é o conhecimento dos experimentados, portanto, a comunidade dos conhecedores, que aliás são raros. A universalidade do gosto é estatística: o que de uma forma permanente é altamente apreciado pelo maior número de pessoas, isso deve ser tido por belo e bom. Hume até concede que "as normas universais do gosto são as mesmas para a natureza humana em geral»; mas as diferenças entre os indivíduos, as deficiências e os preconceitos de cada um deles, as diferenças entre culturas, países e épocas tornam muito improvável, senão até impossível, o acordo inequívoco e duradouro num juízo de gosto.

${ }^{36}$ «Man könnte sogar den Geschmack durch das Beurteilungsvermögen desjenigen, was unter Gefühl an einer gegebenen Vorstellung ohne Vermittlung eines Begriffs allgemein mitteilbar macht, definieren.» KU §40, Ak V 295.
} 
gosto conferindo-lhe uma validade exemplar, é uma simples norma ideal, cuja pressuposição poderia permitir que cada um estabelecesse como regra um juízo que estivesse de acordo com ela e a satisfação num objecto que nela se exprime. Esta norma indeterminada de um sentido comum é efectivamente pressuposta por nós, como se prova pela nossa presunção de proferir juízos de gosto.

Por muito complexa e rebuscada que possa parecer - ou mesmo ser uma tal solução, ela revela-se de uma impressionante novidade e fecundidade. Em primeiro lugar, porque não precisa de fundar a universalidade dos juízos estéticos numa ordem do conhecimento, mantendoa sim no plano do sentimento: há uma universalidade e capacidade de comunicação universal dos sentimentos que não depende da - nem passa pela - ordem dum conhecimento objectivo e intelectual, conceptualizado e argumentado com razões objectivas de ciência. Em segundo lugar, esse «sentimento comunitário» ou "sentido comum» é mais originário do que a capacidade de pensar e comunicar pensamentos ou ideias logicamente, o que coloca o sentimento estético num plano mais fundo da subjectividade humana, a que Kant chama o Gemüt (o ânimo, o espírito: animus, mens - o sentimento de unidade de todas as faculdades anímicas, por isso Kant também fala de sentimento vital ou de vida - Lebensgefühl). Em terceiro lugar, esse «sentido comum» (Gemeinsinn) é mesmo comum a todos, isto é, qualquer ser humano o possui, pelo que a capacidade para o sentimento estético ou para emitir apreciações estéticas é muito mais básica e fundamental nos seres humanos do que a capacidade para o conhecimento científico e para emitir juízos lógicos, que supõe cultivo e treino. A capacidade estética - para a apreciação estética, para ter sentimentos estéticos ou para emitir juízos de gosto - não está, por isso, reservada a alguns indivíduos com qualidades especiais, mas é originariamente dada a todos os seres humanos pelo simples facto de serem humanos. Em suma: a ordem de onde brota o sentimento estético é mesmo mais originária do que a ordem do entendimento ou da razão, e há uma comunicação autónoma dos sentimentos que não passa pelas vias da comunicação intelectual ou racional. O a priori kantiano da comunicabilidade humana sobre que se funda toda a civilização, a cultura, a sociabilidade e até a existência política é de matriz estética: é um sentimento. Mas esse sentimento, não sendo da ordem do conhecimento intelectual, é todavia da ordem da reflexão: o juízo estético ou de gosto é um acto duma faculdade também ela peculiar, a faculdade de julgar reflexionante, que não se deve confundir com a vulgar faculdade de emitir juízos lógicos ou científicos, mas deve sim entender-se como

[...] a capacidade de ajuizamento que, na sua reflexão, toma em consideração em pensamento (a priori) o modo de representação de qualquer outro, como 
que para ater o seu juízo à inteira razão humana e assim escapar à ilusão que, a partir de condições privadas subjectivas - as quais facilmente poderiam ser tomadas por objectivas - teria influência prejudicial sobre o juízo. ${ }^{37}$

\title{
E o $§ 40$ conclui:
}

\begin{abstract}
O gosto poderia ser chamado sensus communis e o juízo estético, com muito mais razão do que o juízo intelectual, pode ser chamado um sentido comum a todos [eines gemeinschaftliches Sinnes], se se quiser empregar a palavra sentido [Sinn] como um efeito da simples reflexão sobre o ânimo [Gemüt]; pois aí entende-se por sentido [Sinn] o sentimento de prazer [Gefühl der Lust]. Poder-se-ia até definir o gosto como o poder de apreciação [Beurteilungsvermögen] daquilo que, numa dada representação e sem mediação de um conceito, torna universalmente comunicável o nosso sentimento. $^{38}$
\end{abstract}

Nos parágrafos 56 e 57 da obra, Kant aborda o mesmo problema, discutindo alguns lugares comuns que costumam ouvir-se a respeito das questões estéticas, a saber, que «cada qual possui o seu próprio gosto», ou que «acerca dos gostos não se disputa» (de gustibus non disputandum).

A primeira fórmula pressupõe que o gosto é um assunto privado e incomunicável; a segunda pode, à primeira vista, considerar-se uma réplica da primeira, mas parece pressupor que, mesmo que o juízo de gosto fosse objectivo, não seria possível reduzi-lo a conceitos determinados e provar a sua objectividade com argumentos. Tanto num caso como no outro, nega-se a pretensão de universalidade e de comunicabilidade, qualidades que os juízos estéticos parecem, não obstante, reivindicar.

Ora, Kant pensa que entre aquelas duas sentenças há lugar para uma terceira, que seria esta: "acerca do gosto é possível pleitear (streiten), ainda que não seja possível disputar (disputieren) [...], pois onde é permitido pleitear, é necessário que haja a esperança de se chegar a um acordo» (Denn worüber es erlaubt sein soll zu streiten, da muss Hoffnung sein, unter einander übereinzukommen). ${ }^{39}$ Esse presumido e esperado acordo, porém, não sendo constrangido por nenhum argumento objectivo, só pode aspirar a ser o resultado do livre assentimento dos parceiros da discussão. Isso explicaria a pretensão com que um juízo de gosto se apresenta, quando o formulamos, de, por assim dizer, exigirmos de cada qual que concorde conosco, como se isso constituísse para ele um dever (gleichsam als Pflicht

\footnotetext{
${ }^{37}$ Ak V, 294

${ }^{38} \mathrm{Ak} \mathrm{V}, 295$.

${ }^{39} \mathrm{KU} \S 56 ; \mathrm{Ak} \mathrm{V}, 338$.
} 
jedermann zugemutet werde), sem contudo termos o direito de o obrigar a que o aceite. ${ }^{40}$

Kant mantém e garante assim um equilíbrio tenso - nunca dado por definitivamente adquirido, mas sempre a exigir negociação, conversação ou discussão - entre a individualidade inalienável da experiência estética e a sua comunicabilidade e abertura à universalidade. O meu juízo, sendo originariamente meu, abre-se, porém, à comunicação e espera ser acolhido por todos aqueles que partilham comigo a condição de seres humanos. Kant chega mesmo a dizer que essa comunicabilidade universal dos sentimentos se funda numa espécie de «contrato originário que é ditado pela própria humanidade». ${ }^{41}$

Mas, como acima foi dito, Kant parece hesitar a respeito da melhor solução para garantir a necessidade e universalidade dos juízos estéticos. Ou, pelo menos, vê-se na necessidade de reforçar a sua ideia dum «sentido comum estético» com a do sentimento moral, como fundamento para garantir a necessidade e a universalidade que aqueles juízos reivindicam. ${ }^{42}$ Isso é particularmente visível na abordagem que o filósofo faz do sentimento do sublime, na qual, como vimos antes, pôs em evidência o íntimo e profundo parentesco que esse sentimento tem com o sentimento moral. No § 29, Kant declara de forma inequívoca que

O juízo sobre o sublime da natureza [...] tem o seu fundamento na natureza humana e mais precisamente naquilo mesmo que, juntamente com o são entendimento se pode esperar e exigir de cada qual, a saber, a disposição para o sentimento das ideias (práticas), isto é, para o sentimento moral [in der Anlage zum Gefühl für (pracktische) Ideen, d. i. zu dem moralischen]. Sobre isso funda-se então a necessidade de assentimento do juízo de outros

\footnotetext{
$\overline{40} \mathrm{KU} \S 40, \mathrm{Ak}$ V, 296. Foi essa muito peculiar natureza do juízo de gosto que levou Hannah Arendt (Lições sobre a Crítica do Juízo, postumamente publicadas) a reconhecer, nesse tópico, não tanto as virtualidades para compreender as questões estéticas, quanto o núcleo mais original e fecundo para pensar a filosofia política de Kant e a própria essência do político.

${ }^{41} \mathrm{KU} \S 41$

${ }^{42}$ A associação entre o bom e o belo estava difusa na tradição filosófica desde Platão e encontra expressão em muitos ensaios de autores do século XVIII. Já no início dos anos 70 (Aus einer Logikvorlesung, Logik-Philippi [May 1772]; Ak XXIV, Berlin, 1966), Kant declara: «Das Gute ist der essentiale Grund des Schönen. Das Wohlgefallen ist nur ein akzidentaler und die Gründe desselben zufällig.» (apud J. Kulenkampf. Materialien..., p. 111). Ver abaixo, na nota 53, passagens das Lições de Antropologia e da Correpondência que afirmam não só uma íntima afinidade entre o sentimento estético e o sentimento moral, mas sugerem mesmo que o que garante a universalidade do juízo estético é a sua origem no sentimento moral.
} 
com o nosso acerca do sublime, a qual ao mesmo tempo incluímos neste juízo. Pois assim como censuramos de carência de gosto aquele que é indiferente ao ajuizamento de um objecto da natureza que achamos belo, assim dizemos que não tem nenhum sentimento aquele que permanece inerte junto ao que julgamos sublime. Exigimos, porém, ambas as qualidades de cada homem e também as pressupomos nele, se ele tem alguma cultura; com a diferença apenas de que exigimos a primeira terminantemente de qualquer um, porque a faculdade do juízo nisso refere a imaginação apenas ao entendimento como faculdade dos conceitos; a segunda, porém, porque ela aí refere a faculdade da imaginação à razão como faculdade das ideias, exigimo-la somente sob uma pressuposição subjectiva (que porém nos cremos autorizados a poder imputar a qualquer um), ou seja, a do sentimento moral no homem, e com isso também atribuímos necessidade a este juízo estético.

\section{E conclui:}

Nesta modalidade dos juízos estéticos, a saber, da necessidade a eles atribuída, reside um momento capital para a crítica da faculdade de julgar. Pois ela faz precisamente reconhecer neles um princípio a priori e subtrai-os à psicologia empírica, onde, de contrário, ficariam sepultados sob os sentimentos de deleite e de dor [Gefühlen des Vergnügens un Schmerzens] (somente sob o epíteto, que nada diz, de se tratar de um sentimento mais requintado [eines feinern Gefühls]), colocando-os e, mediante eles, a faculdade de julgar [Urteilskraft], na classe daqueles que têm por fundamento princípios a priori, fazendo-os passar enquanto tais para a filosofia transcendental. ${ }^{43}$

Há assim, nos juízos estéticos, uma dialéctica entre o privado (o meramente subjectivo) e o universal (a comunicabilidade possível e aberta a todos os humanos, o que testemunha uma certa necessidade e objectividade nesses juízos, embora, como vimos, o que constitui propriamente o objecto e a matéria do juízo estético é a mera forma da teleoformidade). Essa dialéctica entre o singular e o universal, no juízo estético, manifesta-se de um modo peculiar na tensão entre o gosto e o génio, entre a expectativa de acordo universal dos sentimentos e a exigência do absoluto daquela forma superlativa de individualidade que, na suas suas criações ou produções, não obedece a regras dadas, porém, através delas, cria as regras que servirão depois a outros de referência.

A noção de génio desenvolveu-se ao longo do século XVIII, vindo a tornar-se uma categoria essencial da Estética do Romantismo e do Idealismo e, por vezes, até a absolutizar-se, concebida como uma figura superlativa da

\footnotetext{
${ }^{43} \mathrm{KU} \S 29$, último parágrafo.
} 
subjectividade criadora que nos artistas se exprime. ${ }^{44}$ Kant foi dos pensadores setecentistas que mais contribuiu para a elaboração do sentido estético dessa noção, sublinhando as qualidades e faculdades que são requeridas para que alguém possa ser considerado génio. Em particular, a imaginação, enquanto livre poder de criar ideias estéticas, mas ao mesmo tempo o juízo para apreciar a sua pertinência (Zweckmässigkeit) e até o entendimento para encontrar o modo de as comunicar. Do génio exige-se que dê alma ou espírito às suas obras, graças ao que elas se tornam efectivamente cheias de significado (sinnreich) e inspiradoras para outros. Requer-se, por fim, que ele tenha também gosto, isto é, capacidade de apreciar ou ajuizar a pertinência das suas obras e a sua capacidade de serem apreciadas e significativas para outros.

Apesar de toda a importância que atribui ao génio, no contexto do seu pensamento estético, Kant tenta manter o equilíbrio entre dois princípios: o da apreciação e o da criação original, a exigência de comunicabilidade universal representada pelo princípio do gosto e a instauração original do sentido pela individualidade criadora que é o génio, o qual não obedece às regras feitas ou já estabelecidas da arte, mas através de cuja criação é como se a própria natureza desse regras à arte e se constituísse como referência ideal do gosto para os vindouros. Esse equilíbrio entre os dois princípios um, representado na noção de gosto e o outro, na noção de génio - logo será rompido na geração pós-kantiana, romântica e idealista, para a qual o génio (identificado com o artista) se institui como princípio absoluto. Em suma, Kant conclui que, em caso de conflito entre a exigência do génio e a exigência do gosto, aquele deve ser parcialmente sacrificado, precisamente para que a sua criação seja acolhida e reconhecida e possa assim manifestar e exercer toda a sua fecundidade no espaço da comunidade humana. A extraordinária riqueza de ideias e a ilimitada liberdade da imaginação, qualidades peculiares que se reconhece ao génio, devem ceder perante a exigência de pertinência (Zweckmässigkeit) requerida pelo gosto ou faculdade de julgar. Na linguagem de Kant:

O gosto é [... ] a disciplina do génio; ele corta-lhe as asas, torna-o civilizado e polido [beschneidet diesem sehr die Flügel und macht es gesittet oder geschliffen]; mas ao mesmo tempo dá-lhe uma orientação, indicando-lhe em que sentido e até onde ele deve estender-se para poder permanecer pertinente [zweckmässig] e, na medida em que introduz clareza e ordem na profusão dos pensamentos, torna as suas ideias consistentes, capazes de obterem uma aprovação duradoura e ao mesmo tempo universal e de serem seguidas por outros e assim promoverem uma cultura sempre crescente. Se, por

\footnotetext{
${ }^{44}$ Sobre a concepção kantiana do génio, veja-se: O. Schlapp. Kants Lehre vom Genie und die Entstehung der Kritik der Urteilskraft. Göttingen, 1901; Jürgen Saartrowe. Genie und Reflexion. Zu Kants Theorie des Ästhetischen. Neuburgweier/Karlsruhe, 1971.
} 


\begin{abstract}
conseguinte, em caso de conflito entre estas duas propriedades algo num produto [artístico] deve ser sacrificado, deve sê-lo preferentemente do lado do génio; e o juízo [faculdade de julgar], que nos assuntos da bela arte profere a sentença a partir de princípios próprios, autorizará que se prejudique antes a liberdade e a riqueza da imaginação do que o entendimento. ${ }^{45}$
\end{abstract}

Em suma, se o gosto - o juízo - "Corta as asas ao génio», não é por certo para impedi-lo de voar, mas sim para que o seu voo se mantenha a uma altura tal que as suas obras possam ainda ser vistas, apreciadas, compreendidas e fecundas para a sociedade e comunidade dos homens à qual ele as dirige e as propõe. Essa relativa precedência que Kant reconhece ao gosto sobre o génio - por conseguinte, ao juízo reflexionante sobre a imaginação - explica que a sua obra tenha por título "Kritik der Urteilskraft», e não "Kritik der Einbildungskraft», como poderia muito bem tê-lo, se o acento tivesse sido posto na faculdade estética criadora por excelência e não, como foi o caso, na faculdade apreciadora, a qual é chamada a julgar da pertinência das criações do espírito, mesmo quando elas trazem o selo do génio. Na hora de decidir a qual das faculdades do ânimo atribuir o papel fundamental de mediação entre as outras faculdades e de administração orgânica de toda a vida espiritual, Kant escolheu inequivocamente o juízo, designadamente o juízo reflexionante. ${ }^{46}$ Colocado no ponto de viragem de dois regimes do pensamento estético, ao mesmo tempo que leva um ao limite e abre ao outro as portas, Kant revela-se, todavia, mais como sendo ainda o representante de uma estética classicista do gosto e da reflexão contemplativa do que como o incondicional paladino de uma estética romântico-idealista do génio, entendido como um eu individual absoluto que fosse deixado entregue à liberdade sem peias - à arbitrariedade - da sua inesgotável imaginação criadora.

3 Carácter mediador da beleza e matriz estética da civilização humana

Já vimos que o pensamento estético do século XVIII se elaborou, na sua maior parte, em torno da categoria do gosto - e que essa categoria tinha, para além do seu sentido estético e, de resto, a ele ligado, também um eminente sentido social. Esse aspecto é igualmente vincado por Kant, o qual não só correlaciona o interesse pela beleza à condição originariamente social do homem, mas vê nesse interesse o princípio sobre o qual se funda e se

\footnotetext{
${ }^{45} \mathrm{KU} \S 50$.

${ }^{46}$ Aspecto este destacado por Hannah Arendt, na sua interpretação da filosofia política de Kant e da Crítica do Juízo.
} 
desenvolve a civilização humana, desde as formas mais elementares às mais refinadas, sugerindo assim a matriz e inspiração estéticas de toda a civilização. O filósofo faz notar que só nos interessamos pelo belo, em sociedade:

Um homem, abandonado numa ilha deserta, não adornaria para si só nem a sua cabana nem a si próprio, nem procuraria flores, e muito menos as plantaria para se enfeitar com elas; mas só em sociedade lhe ocorre ser não simplesmente um homem, mas também um homem fino à sua maneira (no que se pode ver o começo da civilização); pois é como tal que se ajuíza aquele que é inclinado e apto a comunicar o seu prazer a outros e ao qual um objecto não satisfaz se não se pode sentir a complacência do mesmo em comunidade com outros. [...] E assim, de início, por certo somente atractivos, por exemplo, cores para pintar-se (o rocou entre os caribenhos e o cinabre entre os iroqueses), ou flores, conchas, penas de pássaros belamente coloridas; com o tempo, porém, também belas formas (como em canoas, vestidos, etc.), que não comportam absolutamente nenhum deleite, isto é, complacência do gozo, tornam-se importantes em sociedade e são objecto de um grande interesse; até que, finalmente, a civilização, chegada ao ponto mais alto, faz disso quase o objectivo principal da inclinação refinada e as sensações serão consideradas somente valiosas na medida em que elas possam ser universalmente comunicadas. ${ }^{47}$

Parece-me ser muito significativo o facto de Kant apontar desse modo, tão claramente, a matriz estética como inspiradora do processo e desenvolvimento da civilização, da cultura e da história humanas, da própria vida política enquanto organização da vida em sociedade. O filósofo reconhece que o cultivo do gosto prepara até o processo da moralização da humanidade, na medida em que leva os homens a superar os prazeres sensíveis e os interesses meramente privados e a partilhar os seus sentimentos, educando-os no sentido de abandonarem as formas rudes e bárbaras de convivência, próximas ainda da condição animal, para adoptarem progressivamente formas de civilidade que promovem o agrado geral e que os antigos designavam pela expressão humaniora, isto é aquelas coisas ou assuntos que são "os mais humanos de todos» e por isso são capazes de interessar a todos os homens ou ao maior número possível de homens. ${ }^{48} \mathrm{O}$

${ }^{48}$ Embora o tenha feito por uma torção hermenêutica, foi com toda a razão que Hannah Arendt apontou a extraordinária fecundidade da abordagem kantiana do juízo de gosto, tanto para se compreender o cerne da filosofias política kantiana, quanto para uma refundação filosófica do sentido da existência social e política dos homens. Veja-se, a propósito, o meu ensaio «Da estética como filosofia política: Hannah Arendt e a sua interpretação da Crítica do Juízo de Kant». In: Hannah Arendt: luz e sombra. Lisboa: Centro de Filosofia da Universidade de Lisboa, 2007, p. 157-192.
} 
conjunto de competências que sob esse termo se designa não resulta de regras e preceitos, mas supõe o cultivo individual e livre das faculdades humanas estéticas, nomeadamente da imaginação e do juízo, e Kant relaciona-o expressamente com o universal sentimento de participação que é expresso pela palavra Humanität e com o poder que os seres humanos têm de comunicarem entre si e universalmente os respectivos sentimentos íntimos, e de se associarem e organizarem em formas de existência social e política, mormente naquela forma qualificada que compatibiliza a liberdade, a igualdade e a coerção legal, como é a forma da república. A cultura e educação estéticas constituem uma propedêutica para a cultura política. Escreve Kant, no § 60:

\begin{abstract}
Chamamos a isso as humaniora, presumivelmente porque Humanidade [Humanität] significa, por um lado, o universal sentimento de participação [allgemeine Theilnehmungsgefühl] e, por outro, a faculdade de poder comunicar-se íntima e universalmente; estas propriedades ligadas entre si constituem a socialidade conveniente à humanidade [die der Menschheit angemessene Geselligkeit] pela qual ela se distingue da limitação animal. A época e os povos, nos quais o activo impulso para a socialidade legal [Trieb zur gezetlichen Geselligkeit], mediante o qual um povo constitui uma república duradoura [dauerndes gemeines Wesen ausmacht], lutou com as grandes dificuldades que envolvem a difícil tarefa de unir a liberdade (e portanto também e igualdade) com a coerção (baseada mais no respeito e submissão por dever do que por medo): uma tal época e um tal povo tiveram que inventar primeiro a arte da comunicação recíproca das ideias [Kunst der wechselseitigen Mittheilung der Ideen] da parte mais culta com a mais rude, a sintonização [Abstimmung] do desenvolvimento e do refinamento da primeira com a simplicidade e originalidade naturais da segunda, inventando assim entre a cultura superior e a simples natureza aquele meio [Mittel] que constitui também para o gosto, enquanto sentido humano universal, o padrão de medida correcto, que não pode ser indicado por nenhuma regra universal.
\end{abstract}

Mas não só: o cultivo do gosto é também uma propedêutica para a moralidade. «O gosto» - escreve Kant - "como que torna possível a passagem do estímulo sensível para o interesse moral habitual, sem um salto muito violento». ${ }^{49}$ Por certo, também é verdade o inverso, a saber: que o desenvolvimento das ideias morais e o cultivo do sentimento moral constituem a verdadeira propedêutica para a fundação e promoção do gosto. Tal circularidade dá testemunho não de uma contradição, mas do íntimo parentesco que existe entre os dois sentimentos, o estético e o moral, parentesco e solidariedade sempre pressupostos e muitas vezes expressamente afirmados por Kant, como neste caso:

\footnotetext{
${ }^{49}$ «Der Geschmack macht gleichsam den Übergang vom Sinnereiz zum habituellen moralischen Interesse ohne einen zu gewaltsamen Sprung möglich.» Ak V, 354.
} 
O gosto é no fundo um poder de apreciar [Beurteilungsvermögen] o modo de tornar sensíveis [Versinnlichung] as ideias morais e porque é também deste poder bem como da grande receptividade para o sentimento derivado daquelas ideias (a que chamamos sentimento moral) que decorre aquele prazer que o gosto proclama como válido para a humanidade em geral e não simplesmente para o sentimento pessoal próprio de cada um, torna-se evidente que a verdadeira propedêutica para a fundação do gosto é o desenvolvimento das ideias morais e o cultivo do sentimento moral; pois só no caso de a sensibilidade chegar a estar conforme com este último é que o gosto autêntico pode receber uma forma determinade e imutável. ${ }^{50}$ (§ 60).

É essa função mediadora entre o natural e o moral e essa capacidade educadora, civilizadora e mesmo moralizadora, evidenciada pelo gosto e pelo sentimento estético o que veio a constituir o tema central das Cartas sobre a educação estética do Homem (1795), de Schiller, obra que o seu autor reputava como uma aplicação dos princípios da filosofia moral e estética kantiana e uma interpretação do seu genuíno espírito. ${ }^{51}$

Contudo, a íntima e conatural solidariedade entre o gosto - sentimento estético - e a moralidade não se verifica apenas na capacidade que o primeiro tem para insensivelmente preparar os indivíduos para o segundo. Passagens há na própria Crítica do Juízo e em outras obras posteriores de Kant, nas quais o filósofo aponta o íntimo parentesco entre o sentimento estético do belo e do sublime da natureza e o sentimento moral, em algumas chegando mesmo a sugerir uma origem moral do sentimento estético, o que, à primeira vista, parece comprometer a proclamada autonomia deste último, mas, na verdade, o que faz é sublinhar a organicidade e harmonia das faculdades do espírito, as quais compete precisamente ao sentimento estético manifestar. ${ }^{52}$

\section{${ }^{50} \mathrm{KU} \S 60$.}

51 «Não quero ocultar a origem kantiana da maior parte dos princípios em que repousam as afirmações que se seguirão.» Briefe I. E, numa carta a Kant (de 20.02.95), considera as Cartas (de que envia as 17 primeiras) como "fruto do estudo dos escritos kantianos» e espera que o filósofo «não dê pela falta do espírito da sua filosofia nessa aplicação que ele dela faz» (dass Sie den Geist Ihrer Philosophie in dieser Anwendung derselben nicht vermissen).

${ }^{52}$ Anthropologie-Vorlesung (Anon-Starke, 2, p. 39) "Jedes Geschmacksurteil hat einen Grund a priori und kann nicht aus Erfahrung abgeleitet werden. [...] Der Grund a priori aber liegt in der Anlage zur Moralität in unserm Subjecte, welche macht, dass alle Menschen an dieser oder jener Sache ein Gefallen finden müssen. Der wahre und ächte Geschmack ist unzertrennlich vom moralischen Gefühle." (Semestre de Inverno 1790/91, apud H. Klemme, "Einleitung" à sua ed. da KU, Meiner, Hamburg). Na Anthropologie (Ak VII, 244): "Nun ist das Wohlgefallen, was [...] als allgemeingültig betrachtet werden kann, weil es Notwendigkeit (dieses Wohlgefallens), mithin ein Prinzip desselben a priori enthalten muss, um als ein solches gedacht werden zu können, ein Wohlgefallen an der 
Já acima destaquei isso, em relação ao sentimento do sublime da natureza. Mas outro tanto se pode dizer a respeito da experiência da beleza da natureza. Comentarei brevemente o § 42:

Afirmo que tomar um interesse imediato pela beleza da natureza (e não apenas ter gosto para apreciá-la) é sempre um sinal de uma boa alma; e que, se este interesse for habitual, ele indica denota pelo menos uma disposição de ânimo favorável ao sentimento moral se de bom grado se associa à contemplação da natureza [Beschauung der Natur]. [... ] O ânimo [Gemüt] não pode meditar [nachdenken] sobre a beleza da natureza sem que ao mesmo tempo se interesse por ela. Este interesse, porém, é moral por afinidade; e aquele que toma um tal interesse pelo belo da natureza, somente pode tomá-lo, na medida em que já antes tenha solidamente fundado o seu interesse no bem moral [am Sittlich-Guten]. Por conseguinte, naquele a quem a beleza da natureza interessa imediatamente, temos razão para supor pelo menos uma disposição para um modo de pensar moralmente bom [zu guter moralischer Gesinnung].

\section{E noutro passo do mesmo parágrafo:}

Este privilégio da beleza da natureza face à beleza da arte [...] de só ela despertar um interesse imediato, concorda com o modo de pensar apurado e profundo e com a sólida maneira de pensar de todos os homens que cultivaram o seu sentimento moral. Se um homem, que tem gosto suficiente para julgar sobre produtos da arte bela com a máxima correcção e finura, de bom grado abandona o salão no qual se encontram aquelas belezas que entretêm a vaidade e em todo o caso os prazeres em sociedade, e se volta para o belo da natureza, para encontrar aí como que uma espécie de volúpia para o seu espírito num curso de pensamentos [um hier gleichsam Wollust für seinen Geist in einem Gedankengange zu finden], que ele nunca pode desenvolver completamente; então consideraremos esta sua escolha com veneração e pressuporemos nele uma bela alma [schöne Seele], o que nenhum versado

Übereinstimmung der Lust des Subjekts mit dem Gefühl jedes anderen nach einem allgemeinen Gesetz, welches aus der allgemeinen Gesetzgebung des Fühlenden, mithin aus der Vernunft entspringen muss: d.i. die Wahl nach diesem Wohlgefallen steht der Form nach unter dem Prinzip der Pflicht. Also hat der ideale Geschmack eine Tendenz zur äusseren Beförderung der Moralität.". Numa Carta a Reichardt (15 Out.1790; Ak XI, 228), falando do propósito que teve com a Crítica do Juízo, ao tratar os traços fundamentais (Grundzüge) da tão difícil de investigar faculdade do gosto (so schweer zu erforschenden Geschmacksvermögen) escreve: "Ich habe mich damit begnügt, zu zeigen: dass ohne sittliches Gefühl es für uns nichts schönes oder Erhabenes geben würde: dass sich eben darauf der gleichsam gesetzmässige Anspruch auf Beyfall bey allem, was diesen Nahmen führen soll, gründe und dass das Subjektive der Moralität in unserem Wesen, welches unter dem Namen des sittlichen Gefühls unerforschlich ist, dasjenige sey, worauf, mithin nicht auf obiective Vernunftbegriffe, dergleichen sie Beurtheilung nach moralischen Gesetzen erfordert, in Beziehung, urtheilen zu können, Geschmack sey: der also keineswegs das Zufällige der Empfindgung, sondern ein (obzwar nicht discursives, sondern intuitives) Princip a priori zum Grunde hat." 
em arte e seu amante pode reivindicar em virtude do interesse que toma por seus objectos. ${ }^{53}$

Tais considerações de Kant - a respeito de um interesse desinteressado que envolve o juízo estético a respeito do belo natural - podem soar estranhas aos nossos ouvidos. Podem até parecer que contradizem o seu esforço por mostrar a peculiaridade e autonomia do juízo estético, que ele não se reduz nem ao meramente agradável na sensibilidade, que não é um juízo teórico que vise o conhecimento dos objectos ou por tal conhecimento seja determinado, nem um juízo moral. Por outro lado, quando actualmente se fala de experiência estética, de imediato somos levados a pensar que se trata de uma determinada capacidade para apreciar objectos ou produtos artísticos de qualquer uma das artes: da pintura, da escultura, da arquitectura, da música, da poesia ou de qualquer outra, pois que o sistema das artes se tem modificado e ampliado ao longo da história. E a maior parte dos estudos que há sobre o pensamento estético de Kant dão-nos frequentemente a ilusão de que o filósofo, quando fala do juízo estético ou do juízo de gosto ou do objecto que os suscita, está a falar tomando por referência imediata a apreciação das obras de arte humanas e a apreciação destas. Mas não é assim. Reconhecidamente, a competência artística e até o conhecimento de obras de arte por parte de Kant era muito reduzido, havendo alguns intérpretes que vão ao ponto de perguntar como é que uma pessoa com tão escasso conhecimento da arte se atreveu a escrever sobre assuntos estéticos. Na verdade, aquela vivência que para Kant constitui a matriz da experiência estética e serve de referência para compreender até o significado da arte humana é a experiência da beleza da natureza, aspecto que passou despercebido a muitos intérpretes do pensamento estético kantiano, desde há dois séculos até à actualidade. ${ }^{54}$ Não obstante, só a atenção a ele permite a compreensão da peculiar concepção de Kant acerca das questões estéticas e da razão pela qual a obra que trata, na sua primeira parte, das questões estéticas é aquela mesma que, na segunda, aborda a

${ }^{53} \mathrm{KU} \S 42 ;$ Ak V, 298-299.

${ }^{54}$ Disso foi Hegel o principal responsável, especulativamente falando. Nas suas Lições sobre Estética, desde o primeiro parágrafo ele decide que nelas se trata de uma filosofia da arte e da beleza artística, com isso significando que toda a teoria estética se centra na obra de arte como produção e afirmação do espírito e da autónoma subjectividade do artista, desqualificando como irrelevante e deixando mesmo fora de consideração tudo o que se refere ao belo natural como algo que, por si mesmo, é desprovido de qualidade ou significado estéticos, só os tendo como reflexo do belo artístico. Hegel radicalizou ainda mais e absolutizou a subjectivização da estética e rompeu aquele equilíbrio tenso e fecundo que na concepção kantiana dos sentimentos estéticos se mantinha entre o sujeito (a arte) e a natureza. 
teleologia da natureza. Que relação existe entre o juízo estético e o juízo teleológico, para que sejam reunidos na mesma obra, atribuídos à mesma faculdade do espírito e pensados sob o mesmo princípio transcendental?

Num passo do último parágrafo da Primeira Introdução que Kant escreveu para a sua Crítica do Juízo, lê-se esta declaração:

\begin{abstract}
Uma observação se impõe: é com respeito à técnica na natureza [Technik in der Natur], e não à da causalidade das faculdades de representação do homem a que chamamos arte (no sentido próprio da palavra), que se investiga aqui a teleoformidade [Zweckmässigkeit] como um conceito regulador da faculdade de julgar, e não o princípio da beleza artística [Kunstschönheit] ou duma perfeição artística [Kunstvollkommenheit], ainda que se possa designar a natureza como técnica [technisch] no seu modo de proceder, ou seja de algum modo como artística [künstlich], se a consideramos como técnica (ou plástica [plastisch]), em virtude de uma analogia segundo a qual a sua causalidade deve ser representada como a da arte. Pois trata-se do princípio da faculdade de julgar simplesmente reflexionante, e não da determinante (ao modo daquela que está no fundamento de todas as obras de arte produzidas pelo homem), e a teleoformidade que aí se encontra deve, por conseguinte, ser apreciada como não-intencional [unabsichtlich], só podendo convir à natureza. E assim a apreciação da beleza artística [Kunstschönheit] deverá ser considerada como mera consequência [blosse Folgerung] dos mesmos princípios que estão na base do juízo sobre a beleza da natureza [Naturschönheit].
\end{abstract}

A última frase do texto permite-nos medir a enorme distância que, a propósito da abordagem das questões estéticas, vai de Kant a Hegel. Se em Kant é a experiência da beleza da natureza que se revela como a matriz originária e o critério de toda a experiência estética e da própria experiência da beleza artística, em Hegel, pelo contrário, é a arte e a beleza artística que constituem o assunto próprio da Estética e só por reflexo destas se poderá ainda falar, embora impropriamente, de algo como a beleza da natureza. Por certo, em Kant - e isso é mais um exemplo do equilíbrio do seu pensamento estético -, embora reconhecida a prevalência da experiência estética da natureza sobre a experiência estética da arte, arte e natureza mantêm-se em tensão fecunda e mutuamente se convocam para reciprocamente se explicarem uma pela outra e, se a mais genuína obra de arte - a bela arte - se deixa pensar como se fosse natureza (Kunst als Natur), assim também a natureza se deixa pensar, na experiência estética e teleológica, como sendo arte ou como sendo gerida intimamente por uma secreta arte (Natur als Kunst). ${ }^{55}$

De Kant a Hegel não foi só isso que mudou no plano da concepção dos problemas estéticos. Foram também, entretanto, desqualificados e abandonados os outros tópicos em torno dos quais girava a estética kantiana,

\footnotetext{
${ }_{55} \mathrm{KU}, \mathrm{Ak} \mathrm{V}, 307,311$.
} 
nomeadamente o "gosto», o "sentimento», o juízo estético reflexionante como um «sentido comum a todos». Hegel só registava um facto histórico-cultural consumado, quando escrevia, num dos parágrafos da Introdução às suas Lições de Estética, que já não se ouvia falar de "gosto», e ele mesmo declara que invocar o sentido comum ou o «sentimento» estético é um modo completamente inadequado de se pretender abordar a arte e a beleza artística, tarefa que exige antes um conhecimento experimentado e especializado. Mas, como que por ironia, o próprio Hegel, que, desde o primeiro parágrafo das Lições de Estética, parecia prometer nelas a apoteose da arte, da subjectividade do artista e da beleza artística, acaba por anunciar já o que se tornará o destino contemporâneo da arte, antecipando-lhe o atestado de óbito, declarando a "morte da arte». ${ }^{56}$ Tendo-a criado e tendo-se reconhecido nela, o espírito que acede à consciência de si já não é capaz de satisfazer-se nela. A arte já só pode ser para ele algo passado, que ele pode por certo ainda pensar, descrever, explicar ou compreender, mas não já verdadeiramente viver. O domínio do sentimento cede perante o domínio do saber filosófico e do conceito. Num mundo dominado pela razão filosófica ou científica, não haverá mais lugar para a arte como algo onde a consciência se reconheça ainda em sua casa, como plenamente realizada e reconciliada consigo mesma. Cada vez mais arrancada ao seu elemento vital, cortado o seu vínculo com a natureza e com a vida social e remetida para a mera subjectividade, a arte já nem sequer se dá como ocasião de um sentimento de vida plena ou de uma vivência do absoluto; ela não é mais a manifestação suprema da vida do espírito, como o fora para os jovens idealistas, entre os quais se contava o próprio Hegel, na sua juventude. ${ }^{57}$ Se o espírito pode ainda pensá-la e ocupar-se dela, é só como algo que para ele é passado e morto. ${ }^{58}$

$\overline{56}$ G. W. F. Hegel. Vorlesungen über die Ästhetik. Frankfurt a.M.: Suhrkamp, 1970. Bd. I, 141-142.

${ }^{57}$ Tenha-se presente o já citado manifesto filosófico conhecido por O mais antigo programa de sistema do Idealismo Alemão, cuja autoria é atribuída a três jovens colegas na Stiftung de Tubinga, que dão pelos nomes de Hölderlin, Schelling e Hegel, e cuja versão manuscrita que até nós chegou terá sido redigida por Hegel. Aí se afirma que «o supremo acto da razão é um acto estético». Na mesma linha vão as teses de Schelling, na sua obra Sistema do idealismo transcendental (1800), onde se podem ler declarações como esta: "O verdadeiro sentido para compreender este modo de filosofia [i. é, a filosofia transcendental] é o estético e, precisamente por isso, a filosofia da arte é o verdadeiro organon da filosofia." (Introdução, § 4, in Schellings Werke. Ed. cit. de M. Schröter, Bd. II, p. 351).

${ }^{58} \mathrm{Tal}$ como os mausoléus das pessoas ilustres da história antiga, os Museus - esses templos ou santuários da arte que se instituíram sobretudo a partir do século XIX e até à actualidade - cumprem simultaneamente a função de monumentos de consagração e celebração e de sarcófagos ou túmulos da arte. E cada vez é mais difícil discriminar o que é digno ou não de ser celebrado ou consagrado por essa instituição. Sobre o debate actual em torno do tópico da «morte da arte», veja-se: BELTING, 1984; LANG, 1984; DANTO, 1997. 
SANTOS, Leonel Ribeiro dos. Kant's conception of aesthetic experience: novelties, tensions and balances. Trans/Form/Ação, (Marília); v.33, n.2, p.35-76, 2010.

ABSTRACT: The aim of this essay is to identify some peculiar aspects of Kant's treatment of aesthetic sentiment, showing his tensions and balances and also his fecundity to the actual philosophical debate concerning aesthetic problems. I try to demonstrate that Kant's meditation represents a singular moment of instable equilibrium between two different paradigms of aesthetic thought: one, that turns on the category of taste (Geschmack), understood as an aesthetic common sense that invokes a social and communitarian preoccupation, the other, that turns on the category of genius (Genie) and assumes the presupposition of the absolute character of the individual subjectivity as source of creativity; one, that rehabilitate the human sensibility (Sinnlichkeit) and the sensible qualities of objects as contemplated or appreciated by the subject, the other based on the idea of inner sentiment (Gefühl), considered as something inalienable and as the absolutely subjective dimension of individual experience.

KEYWORDS: Aesthetic experience. Kant's Aesthetics. Genius. Sensibility. Sentiment. Taste.

\section{Referências}

ARENDT, H. Lectures on Kant's political philosophy. Chicago: University of Chicago Press, 1982.

BAUMGARTEN, A. Ästhetik (Latein/Deutsch). Hamburg: Felix Meiner, 2007.

Meditationes philosophicae de nonnullis ad poema pertinentibus (Latein/Deutsch). Trad. e Introd. de H. Paetzold. Hamburg: Felix Meiner, 1983.

BELTING, H. Likeness and presence: a history of the image before the end of art. Chicago: University of Chicago Press, 1984.

BREITINGER, J. J. Critische Abhandlung von der Natur, den Absichten uind dem Gebrauche der Gleichnisse. Zürich: [s.n.], 1740. Reimpr.: Stuttgart, 1967.

BURKE, E. A philosophical enquiry into the origin of our ideas of the sublime and beautiful (1757). Ed. with Introduction by Adam Phillips. Oxford: Oxford University Press, 1990.

DANTO, A. After the end of art. Princeton: Princeton University Press, 1997.

De DUVE, T. Kant nach Duchamp. München: Boer, 1993.

FERREIRA, Vergílio. Invocação ao meu corpo. Lisboa: Bertrand, 1969.

GADAMER, H.-G. Wahrheit und methode.Tübingen: Mohr, 1975.

HEGEL, G. W. F. Vorlesungen über die Ästhetik. Frankfurt a. Main: Suhrkamp, 1970. 
LANG, B. (Ed.). The death of art. New York: Haven Publishers, 1984.

KANT. I. Beobachtungen über das Gefühl des Schönen und Erhabenen, Kants gesammelte Schriften, Akademie-Ausgabe, Bd. II. Berlin, 1902 ss. Reimpr. Berlin: Walter de Gruyter.

Kritik der reinen Vernunft. Akademie-Ausgabe, Bd. III. Reimpr.: Berlin: $\overline{\text { Walter }}$ de Gruyter, [19-].

. Kritik der Urteilskraft. Akademie-Ausgabe, Bd.V. Reimpr. : Berlin: Walter de Gruyter, [19-].

. Erste Einleitung in die Kritik der Urteilskraft. Ed. de G. Lehmann, Hamburg : Felix Meiner, 1977.

KULENKAMPF, Jens. Materialien zu Kants Kritik der Urteilskraft. Frankfurt a. Main: Suhrkamp, [19—].

LYOTARD, J.-F. L'Inhumain. Causeries sur le temps. Paris: Galilée, 1988.

. Leçons sur l'Analytique du Sublime. Paris: Galilée, 1991.

NAKAZAWA, T. Kants Begriff der Sinnlichkeit. Seine Unterscheidung zwischen apriorischen unde aposteriorischen Elementen der sinnlichen Erkenntnis und deren lateinische Vorlagen. Stuttgart-Bad Cannstatt: Frommann-Holzboog, 2009.

PESSOA, F. Poemas completos de Alberto Caeiro. Ed. de Teresa Sobral Cunha. Lisboa: Presença, 1994.

RIBEIRO DOS SANTOS, Leonel. A razão sensível. Estudos kantianos. Lisboa: Colibri, 1994.

Da estética como filosofia política: Hannah Arendt e a sua interpretação da Crítica do Juízo de Kant. In: FERREIRA, M. L. R. (Ed.). Hannah Arendt: luz e sombra. Lisboa: Centro de Filosofia da Universidade de Lisboa, 2007.

SAARTRÖWE, J. Genie und Reflexion. Zu Kants Theorie des Ästhetischen. Neuburgweier/Karlksruhe, 1971.

SCHELLING, F. W. J. System des transcendentalen Idealismus (1800). Schellings Werke, Bd. II. Ed. M. Schröter: München: Beck'sche Verlagsbuchhandlung,1927ss.

SCHLAPP, O. Kants Lehre vom Genie und die Entstehung der Kritik der Urteilskraft. Göttingen, 1901.

SCHMIDT, H.-M. Sinnlichkeit und Verstand. Zur philosophischen und poetologischen Begründung von Erfahrung und Urteil in der deutschen Aufklärung (Leibniz, Wolff, Gottsched, Bodmer und Breitinger, Baumgarten). München: Wilhelm Fink Verlag, 1982.

VON BORMANN, A. Vom Laienurteil zum Kunstgefühl. Tübingen: Max Niemeyer, 1974. 